\title{
REFINEMENT OF TOPOGRAPHICAL FACTOR FOR ESTIMATING SOIL LOSS AND SEDIMENT YIELD IN EQUATORIAL REGIONS
}

\author{
L. K. Yong ${ }^{1}$, P. L. Law ${ }^{2}$, S. N. L. Taib ${ }^{3}$, D. Y. S. Mah and A. H. Johari ${ }^{4}$ \\ 1,2,3,4,5 Department of Civil Engineering, Universiti Malaysia Sarawak, 93000, Kota Samarahan, Sarawak, Malaysia \\ Date received: 10/07/2018, Date accepted: 25/08/2018 \\ Corresponding author's email: yongleongkong@gmail.com
}

\begin{abstract}
This paper aims to improve the Topographical Factor for estimation soil loss and sediment yield in Equatorial region. In the Revised Universal Soil Loss Equation (RUSLE), Topographical factor (LS) is derived as soil loss amount related to gently-inclined plane surface of $72.6 \mathrm{ft}(22.13 \mathrm{~m})$ slope length and $9 \%$ slope gradient in United States of America (USA). The terrains in equatorial region (especially at construction sites) comprise of more cone-shaped and pyramidshaped characterized with steeper slopes and shorter slope lengths as compared to agricultural lands in USA. Topographical Factors $\left(\mathrm{T}_{\mathrm{T}}, \mathrm{T}_{\mathrm{C}} \& \mathrm{~T}_{\mathrm{P}}\right.$ ) in equatorial region were found as function of sediment yield (SY), surface runoff velocity (RV), and silt and clay compositions (SC). Triangular prism-shaped slope could be used as reference or indicator due to the shape is comparable or almost similar to that of the RUSLE's gently-inclined plane surface. Cone-shaped and pyramid-shaped showed approximately $80 \%$ and $77 \%$, respectively similar to triangular prism-shaped. Therefore, the Topographical Factors for triangular prism-shaped, cone-shaped and pyramid-shaped landscapes in equatorial region: Error! Reference source not found. (Triangular Prism), Error! Reference source not found. (Cone) andError! Reference source not found. (Pyramid).
\end{abstract}

Copyright $\odot 2018$ UNIMAS Publisher. This is an open access article distributed under the Creative Commons Attribution-NonCommercial-ShareAlike 4.0 International License which permits unrestricted use, distribution, and reproduction in any medium, provided the original work is properly cited.

Keywords: Topographical factors, slope length, slope steepness, equatorial.

\subsection{INTRODUCTION}

Topographical Factor (LS) in the Revised Universal Soil Loss Equation (RUSLE) can be defined as the soil loss ratio indicated by unit plot with slope length of $72.6 \mathrm{ft}(22.13 \mathrm{~m}), 6 \mathrm{ft}(1.83 \mathrm{~m})$ width and slope gradient of $9 \%$ as shown in Figure 1 [1]. It is a combined index of the factors that could affect the soil loss amount which are slope length (L) and slope steepness (S). It is a measure of the capacity of overland flow/surface runoff to transport sediment/soil particles [2]. The LS is dimensionless, having LS values (RUSLE experimental values normalized to 72.6-ft slope length and 9\% slope gradient) equal to or greater than zero [2]. The LS was developed by Wischmeier and Smith in 1958, together with other factors - rainfall erosivity (R), soil erodibility (K), cover management (C) and support practice (P) to form the Universal Soil Loss Equation (USLE) for soil loss prediction [1]. The USLE was later revised by Renard et al. in 1997 to become the Revised Universal Soil Loss Equation (RUSLE) for estimation of soil loss amount in agricultural areas [3].

The Revised Universal Soil Loss Equation (RUSLE) by Renard et al. (1997) can be considered as one of the best soil loss estimates for the agricultural sector in temperate regions as it is closely related to the amount of soil loss from agricultural lands [3,4]. The LS values in the RUSLE were evaluated from soil loss data on thirty-seven (37) agricultural/cultivated lands in the eastern USA where the terrain is composed of gently-inclined plane surfaces as illustrated in Figure 1 [1]. However, in equatorial regions, terrain (especially at construction sites) is characterized by steeper slopes and shorter slope lengths as compared to agricultural lands in the eastern USA. Since steeper and shorter hill slopes result in higher overland flows/surface runoffs as compared to RUSLE's 37 experimental sites in the eastern USA, equatorial regions could experience more soil particles being washed downslope. 
Theoretically, the application of RUSLE's LS in equatorial regions would grossly underestimate the soil loss rate and sediment yield.

This study aims to improve the Topographical Factors for different topographical shapes to estimate soil loss amount in equatorial regions; for instance, $\mathrm{T}_{\mathrm{T}}$ for triangular prism-shaped, $\mathrm{T}_{\mathrm{C}}$ for cone-shaped and $T_{P}$ for pyramid-shaped. RUSLE's LS considers gently-inclined plane surfaces only and does not consider $\mathrm{T}_{\mathrm{C}}$ and $\mathrm{T}_{\mathrm{P}}$. RUSLE's LS is generally applicable for four types of land, which are 1) rangeland and other consolidated soil conditions with cover (low ratio of rill to inter-rill erosion), 2) row-cropped agricultural and other moderately consolidated soil conditions with little-to-moderate cover (moderate ratio of rill to inter-rill erosion), 3) freshly prepared construction sites and other highly disturbed soil conditions with little or no cover (high ratio of rill to inter-rill erosion), and 4) thawing soils where most of the soil erosion is caused by surface flow (Table 1). Topographical factor (LS) was revised by Jones et al. (1996) with adopted U.S. Army Land Condition-Trend Analysis (LCTA) Data Gaps and thus proposed LS values (Table 1) for estimation of soil loss rate [5].

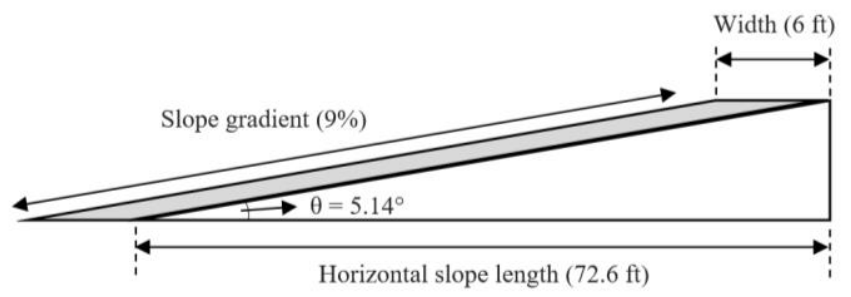

Figure 1: The unit plot shape of RUSLE

Table 1 LS values by previous researchers

\begin{tabular}{|c|c|c|c|c|}
\hline \multirow[b]{2}{*}{ No. } & \multirow[b]{2}{*}{ Typical Applications } & \multicolumn{3}{|c|}{ LS Values (unitless) } \\
\hline & & $\begin{array}{l}\text { Wischmeier \& } \\
\text { Smith (1958) }\end{array}$ & $\begin{array}{c}\text { Renard et al. } \\
(1997)\end{array}$ & $\begin{array}{c}\text { Jones et al. } \\
(1996)\end{array}$ \\
\hline 1. & $\begin{array}{l}\text { Rangelands, pasture, other consolidated soils with } \\
\text { cover }\end{array}$ & \multirow{4}{*}{$0.06-12.90$} & $0.05-34.71$ & 1.00 \\
\hline 2. & $\begin{array}{l}\text { Row-cropped agricultural and other moderately } \\
\text { consolidated soil conditions with little to moderate } \\
\text { cover }\end{array}$ & & $0.05-52.70$ & 2.00 \\
\hline 3. & $\begin{array}{l}\text { Freshly prepared construction sites and other highly } \\
\text { disturbed soil conditions with little or no cover }\end{array}$ & & $0.05-72.15$ & 3.00 \\
\hline 4. & $\begin{array}{l}\text { Thawing soils where erosion is caused by surface } \\
\text { flow }\end{array}$ & & $0.02-10.59$ & 4.00 \\
\hline
\end{tabular}

(Sources: Wischmeier \& Smith, 1958; Renard et al., 1997; Jones et al., 1996)

In most soil erosion studies, soil loss amount is measured by sampling the sediment concentration of the runoff collected at the end of observation plots and then determining the LS values with reference to RUSLE's unit plot (72.6-ft slope length and 9\% slope gradient) [6]. LS values also can be determined by using Digital Elevation Model (DEM), Open-Source C++ Program and Geographic Information System (GIS) which were developed based on topographical shapes (gently-inclined plane surfaces) in the eastern USA where slope length is $72.6 \mathrm{ft}$ and slope gradient is $9 \%$ [7, 8, 9]. However, there are differences between soil loss and sediment yield. Soil loss can be defined as the movement of soil particles regardless of distance within an observation plot, while the amount of soil particles collected at the end of an observation plot is defined as sediment yield as illustrated in Figure 2 [10]. As the smaller soil particles such as silt and clay would be continually displaced during rainfall, soil loss cannot be measured due to the distance of moving soil particles and smaller sizes of soil particles cannot be 
observed. Sediment yield can be measured precisely (by measuring the concentration or total suspended solids of surface runoff) because the soil particles can be collected at the end of the observation plot.

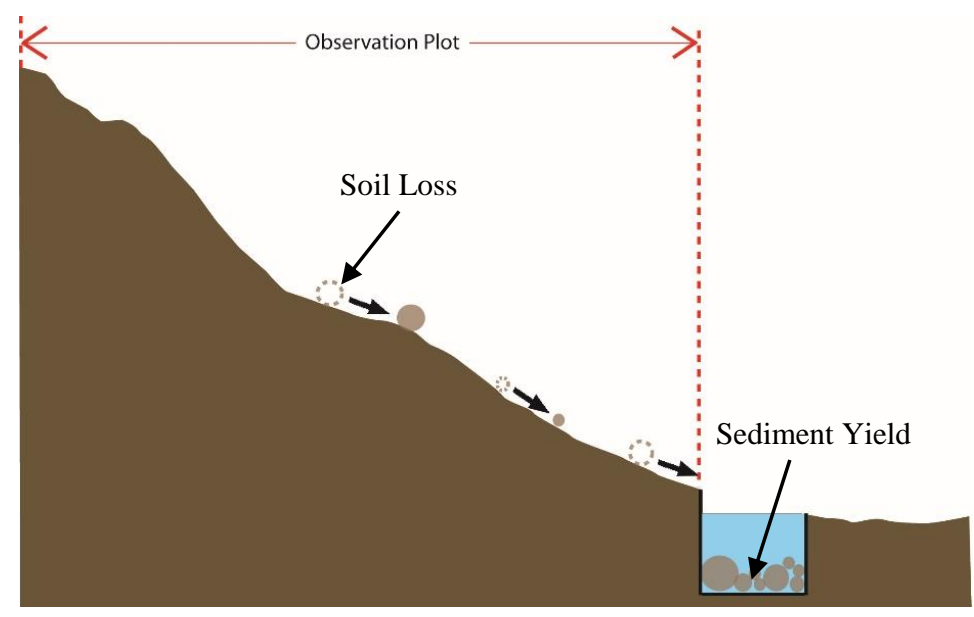

Figure 2 Soil loss and sediment yield

\subsection{METHODOLOGY}

\subsection{SLOPE LENGTH FACTOR, L}

Slope length is defined as the horizontal distance from the origin of overland flow to the point where deposition begins as shown in Figure $3[2,4]$. The amount of soil loss and sediment yield increase with slope length $[2,4]$. Slope length can be related to rill erosion due to surface runoff which is usually measured in less than 400-ft although longer slope lengths of up to 1000-ft are commonly found in United States of America (USA). Slope length can be measured on agricultural lands, while for steeper slopes (slope gradient more than 9\%), slope lengths should be converted to horizontal distance for soil loss estimation by using the RUSLE [2, 4]. Slope lengths are commonly measured on contour maps, however slope lengths estimated from contour maps are usually too long [2, 4]. This is because most maps do not have the details to indicate all concentrated of runoff flow areas that accomplish RUSLE's defined slope length $[2,4]$.

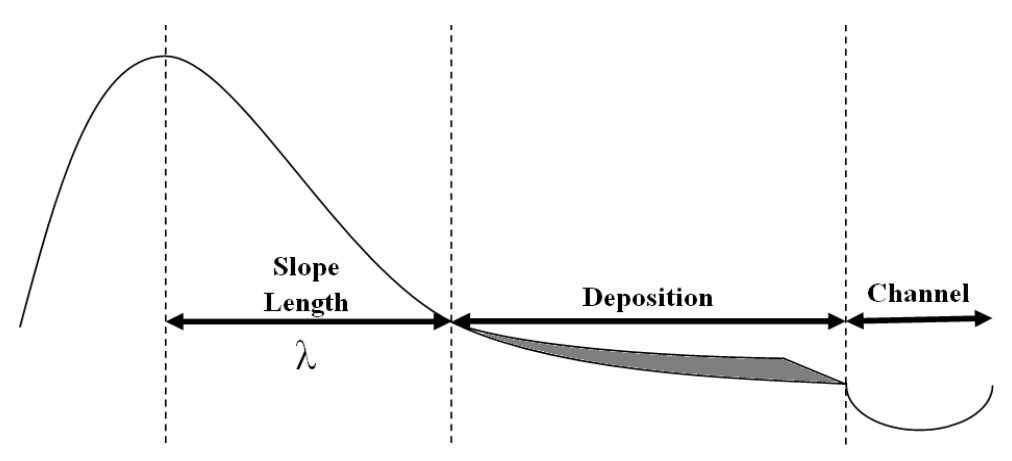

Figure 3 Slope profile defined in the RUSLE

The first equation published by Zingg (1940) for prediction of field soil loss which described the slope length factor is shown below $[6,11]$ :

\section{Error! Reference source not found.}

where L is soil loss amount in mass per unit area per unit time, "Error! Reference source not found." is the slope length in meters, "a" and " $\mathrm{m}$ " are empirical coefficients. Field studies at 37 agricultural sites in the eastern USA were carried out for soil loss data based on the slope profile illustrated in Figure 3 with slope lengths ranging from 30 to $300-\mathrm{ft}$ and slope gradients ranging between 3 to $18 \%$ 
[1]. Average slope length and slope gradient for 37 agricultural sites are $72.6-\mathrm{ft}(22.13-\mathrm{m})$ and $9 \%$, respectively [1]. The slope length of $72.6-\mathrm{ft}(22.13-\mathrm{m})$ was thus adopted/applied in the RUSLE to estimate soil loss as shown in Equations 2 and 3 [1]:

Error! Reference source not found. (unitless, Error! Reference source not found. in feet)

Error! Reference source not found. (unitless, Error! Reference source not found. in meter)

where:

Error! Reference source not found. = Horizontal slope length

Error! Reference source not found. = A variable slope length exponent, unitless.

In the RUSLE, Error! Reference source not found. is related to the ratio Error! Reference source not found. of rill erosion to inter-rill erosion which is shown as a continuously increasing value as stated in the Equation 4.

Error! Reference source not found.

where:

Error! Reference source not found. = Sediment load contributed from rill erosion,

Error! Reference source not found. = Sediment load contributed from inter-rill erosion, and the value of Error! Reference source not found. can be computed as shown in the following equation:

Error! Reference source not found. where:

Error! Reference source not found. = Slope angle in degree.

\subsubsection{SLOPE LENGTH EXPONENT, $\mathrm{m}$}

Slope length exponent $(\mathrm{m})$ is defined as the ratio of rill erosion to inter-rill/sheet erosion. Slope length factor (L) by several authors is dependent on the slope length exponent (m) as tabulated in Table 2. Rill erosion is affected by surface runoff, where higher amount of surface runoff would carry more soil particles in the rill. Inter-rill erosion happens due to the impact of falling raindrops, where larger raindrop size comprises of larger kinetic energy to detach the soil particles. Slope length affects rill and inter-rill/sheet erosion, where longer slope length could yield more severe rill and inter-rill/sheet erosion [4]. The effects of rill and inter-rill erosion have been evaluated separately by using uniform-gradient $(0.2 \%$ to $60 \%)$ plots and thus classified the slope length exponent $(\mathrm{m})$ values into low, moderate and high rill/inter-rill ratio [15]. The result of slope length exponent (m) was adopted in the RUSLE's Lfactor as shown in the Table 3.

Table 2 Slope-length exponents $(\mathrm{m})$ by previous researchers

\begin{tabular}{|c|c|c|c|c|c|}
\hline No. & Researchers & \multicolumn{2}{|c|}{ m Value } & \multicolumn{2}{|l|}{ Remark } \\
\hline 1. & Zingg, 1940 [11] & \multicolumn{2}{|c|}{0.6} & \multicolumn{2}{|l|}{-} \\
\hline 2. & Musgrave, 1947 [12] & \multicolumn{2}{|c|}{0.3} & - & \\
\hline 3. & Wischmeier \& Smith, 1958 [1] & $\begin{array}{c}\mathrm{m} \text { value } \\
0.2 \\
0.3 \\
0.4 \\
0.5\end{array}$ & $\begin{array}{c}\text { Slope gradient } \\
\leq 1 \% \\
1 \% \text { to } 3 \% \\
3.5 \% \text { to } 4.5 \% \\
\geq 5 \%\end{array}$ & $\begin{array}{l}\text { Universal Soil } \\
\text { Equation (USLE) }\end{array}$ & Loss \\
\hline 4. & Moore \& Burch, 1986 [13] & \multicolumn{2}{|c|}{0.4} & & \\
\hline 5. & McCool et al., 1987 [14] & \multicolumn{2}{|c|}{0.5} & \multicolumn{2}{|l|}{-} \\
\hline
\end{tabular}




\begin{tabular}{clcl}
\hline 6. & Moore \& Wilson, 1992 [2] & 0.6 & \\
7. & Renard et al., 1997 [4] & Table 3 & $\begin{array}{l}\text { Revised Universal Soil } \\
\text { Loss Equation (RUSLE) } \\
\text { Location at three sites on } \\
\text { Loess Plateau of China. }\end{array}$ \\
\hline
\end{tabular}

Table 3 Slope-length exponents (m) in the RUSLE for range of slopes and rill/inter-rill erosion classes

\begin{tabular}{cccc}
\hline $\begin{array}{c}\text { Slope } \\
(\%)\end{array}$ & Low & $\begin{array}{c}\text { Rill/Inter-rill Ratio } \\
\text { Moderate }\end{array}$ & High \\
\hline 0.2 & 0.02 & 0.04 & 0.07 \\
0.5 & 0.04 & 0.08 & 0.16 \\
1.0 & 0.08 & 0.15 & 0.26 \\
2.0 & 0.14 & 0.24 & 0.39 \\
3.0 & 0.18 & 0.31 & 0.47 \\
4.0 & 0.22 & 0.36 & 0.53 \\
5.0 & 0.25 & 0.40 & 0.57 \\
6.0 & 0.28 & 0.43 & 0.60 \\
8.0 & 0.32 & 0.48 & 0.65 \\
10.0 & 0.35 & 0.52 & 0.68 \\
12.0 & 0.37 & 0.55 & 0.71 \\
14.0 & 0.40 & 0.57 & 0.72 \\
16.0 & 0.41 & 0.59 & 0.74 \\
20.0 & 0.44 & 0.61 & 0.76 \\
25.0 & 0.47 & 0.64 & 0.78 \\
30.0 & 0.49 & 0.66 & 0.79 \\
40.0 & 0.52 & 0.68 & 0.81 \\
50.0 & 0.54 & 0.70 & 0.82 \\
60.0 & 0.55 & 0.71 & 0.83 \\
\hline
\end{tabular}

\subsection{SLOPE STEEPNESS FACTOR, $\mathrm{S}$}

Soil loss is strongly related to slope steepness that affects surface runoff velocity and infiltration rate. Surface runoff velocity is increasing with the gradient of slope, while the infiltration rate is decreasing $[16,17,18]$. Many classifications of slope steepness for soil and land surveys considered slope gradient of $30 \%$ as a starting point for "steep" slopes $[19,20,21]$. The data used to develop USLE and RUSLE involved slopes only up to $18 \%[2,4,15,21]$. Table 4 shows the slope steepness factor (S) by previous researchers.

Table 4 Slope steepness factor (S value)

\begin{tabular}{|c|c|c|c|}
\hline No. & Researchers & $\mathrm{S}$ value & Remark \\
\hline 1. & Wischmeier \& Smith,1978 [22] & $S=65.41 \sin ^{2} \theta+4.56 \sin \theta+0.065$ & $\begin{array}{c}\text { Universal Soil Loss } \\
\text { Equation (USLE) }\end{array}$ \\
\hline & & $S=10.8 \sin \theta+0.03$ & Slope gradient $<9 \%$ \\
\hline & & $S=16.8 \sin \theta-0.50$ & Slope gradient $\geq 9 \%$ \\
\hline 2. & McCool et al., 1987 [14] & $S=3.0(\sin \theta)^{0.8}+0.56$ & $\begin{array}{l}\text { Slope length }<15 \mathrm{ft} \\
\text { Water drains freely }\end{array}$ \\
\hline & & $S=\left(\frac{\sin \theta}{0.0896}\right)^{0.6}$ & $\begin{array}{l}\text { Thawing soils with } \\
\text { slope gradient } \geq 9 \%\end{array}$ \\
\hline 3. & Moore \& Wilson, 1992 [2] & $S=\left(\frac{\sin \theta}{0.0896}\right)^{1.3}$ & $0<\theta \leq 90^{\circ}$ \\
\hline 4. & Liu et al., 1994 [21] & $S=21.91 \sin \theta-0.96$ & $0<\theta \leq 90^{\circ}$ \\
\hline 5. & Nearing, 1997 [23] & $S=-1.5+\frac{17}{1+e^{2.3-6.1 \sin \theta}}$ & $0<\theta \leq 90^{\circ}$ \\
\hline
\end{tabular}


Most researchers normalized their results to 72.6-ft horizontal slope length and 9\% slope gradient, developed by Wischmeier and Smith (1958) for agricultural lands in United States of America (USA); where the topographical shapes are "gently-inclined plane-surfaced" and characterized by relatively flat and long slope length $[4,24,25]$, while the terrains in equatorial regions especially at construction sites, comprise of comparatively more cone-shaped and pyramid-shaped topography characterized with steeper slopes and shorter slope lengths. Hence, higher rainfall intensity coupled with steeper and shorter hill slopes would result in higher surface runoff velocity (as compared to RUSLE's 37 experimental sites in Eastern USA), could lead equatorial regions to experience more soil particles being washed down the slope. Table 5 compares the differences in topographical shapes between RUSLE and equatorial regions.

Table 5 RUSLE topographical shape vs equatorial

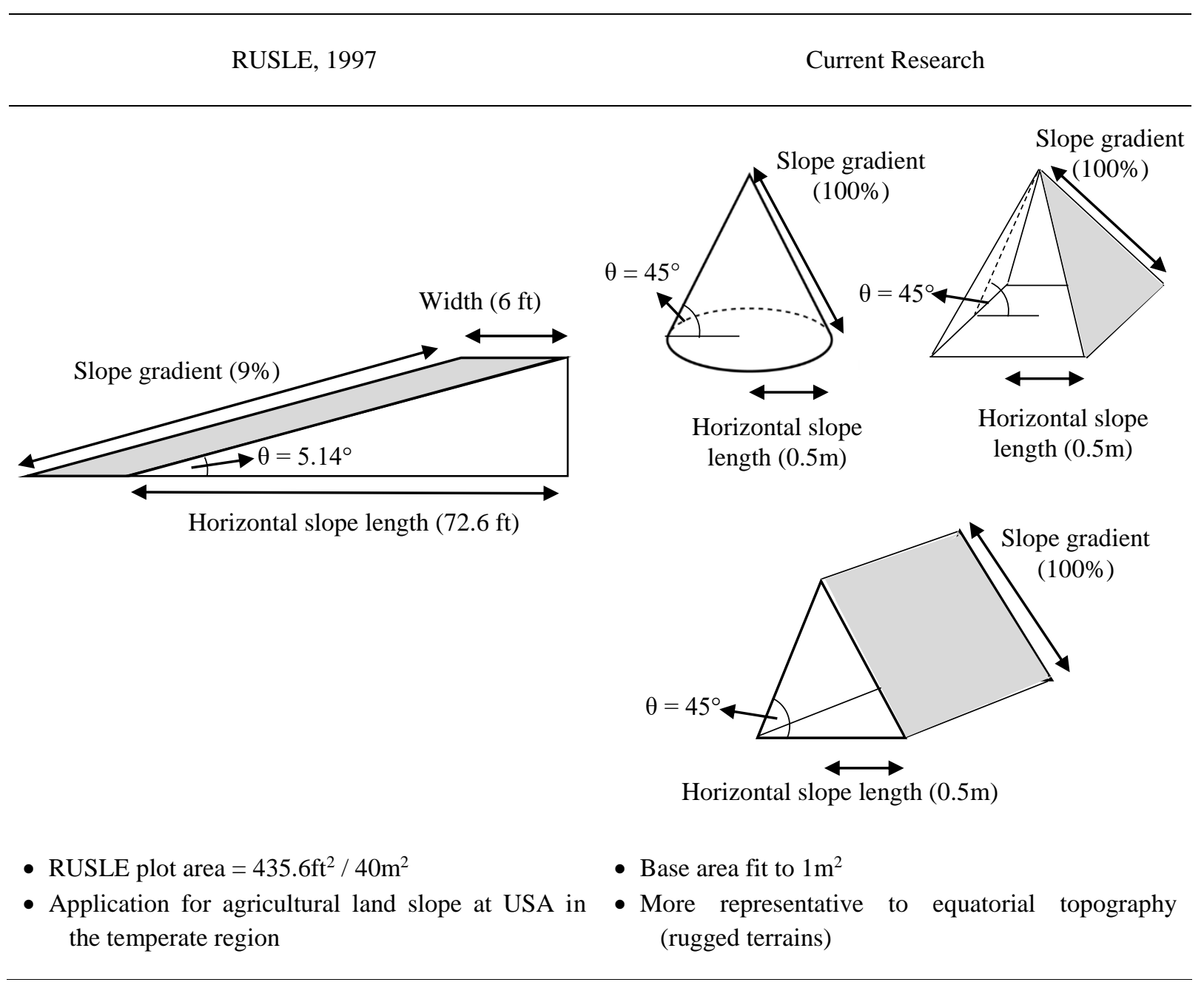

\subsection{TOPOGRAPHICAL SHAPE MOULDS}

Three topographical shapes (triangular prism, cone and pyramid) were developed to observe the surface runoff patterns, surface runoff velocity and amount of sediment yield. These topographical shapes were made by using fabricated moulds in accordance with Standard Proctor Test (SPT). The base area of the fabricated moulds were fixed to $1 \mathrm{~m}^{2}$ and divided into three compartments for the easement of soil filling and compaction. The method of soil compaction and number of blows were also in accordance 
with SPT. Triangular prism and pyramid moulds were fabricated by using $12-\mathrm{mm}$ thick plywood, and the cone mould was made by using iron and aluminum because plywood could not make round shape. Table 6 shows the experimental moulds.

Table 6 Experimental moulds

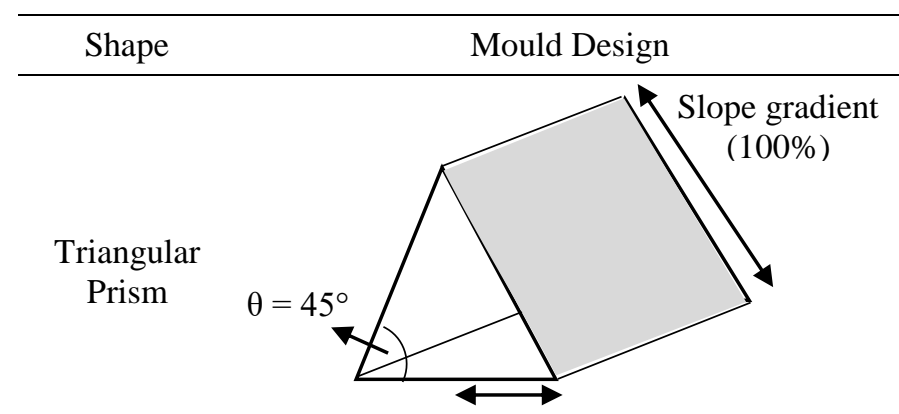

Horizontal slope length $(0.5 \mathrm{~m})$
Cone

Pyramid
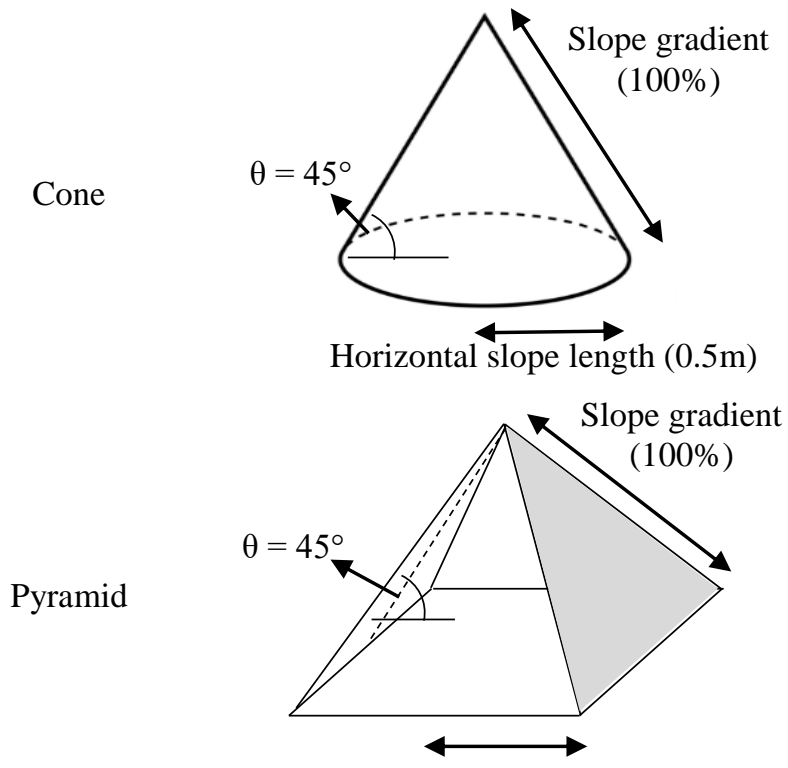

Horizontal slope length $(0.5 \mathrm{~m})$
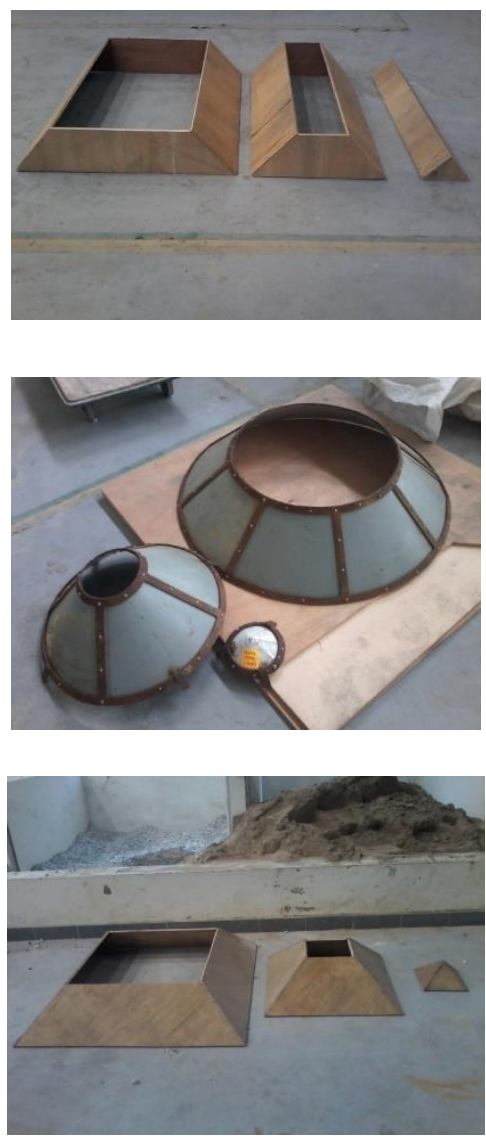

\subsection{SOIL SAMPLE PREPARATION}

Two mineral soil samples were collected around Kuching, Sarawak: Sample Soil A was collected at a field near Santubong River and Sample Soil B was collected from a slope located at Kota Samarahan. Soil analysis for Grain Size Distribution and Standard Proctor Test (SPT) were carried out to obtain particle size distribution, soil composition, soil classification, optimum moisture content and maximum dry density. Two kilogram $(2 \mathrm{~kg})$ total mass of oven dried soil samples A and B were used for grain size distribution analysis as shown in Figure 4. The soil samples were placed on woven wire mesh sieves $(63 \mu \mathrm{m}-14 \mathrm{~mm})$ and separated into several sizes by using a sieve machine. All sieve pans were weighed before and after shaking; subsequently the percentage retained of each sieve was determined. Outcomes of grain size distribution and soil classification are shown in Figure 5 and Figure 6. 

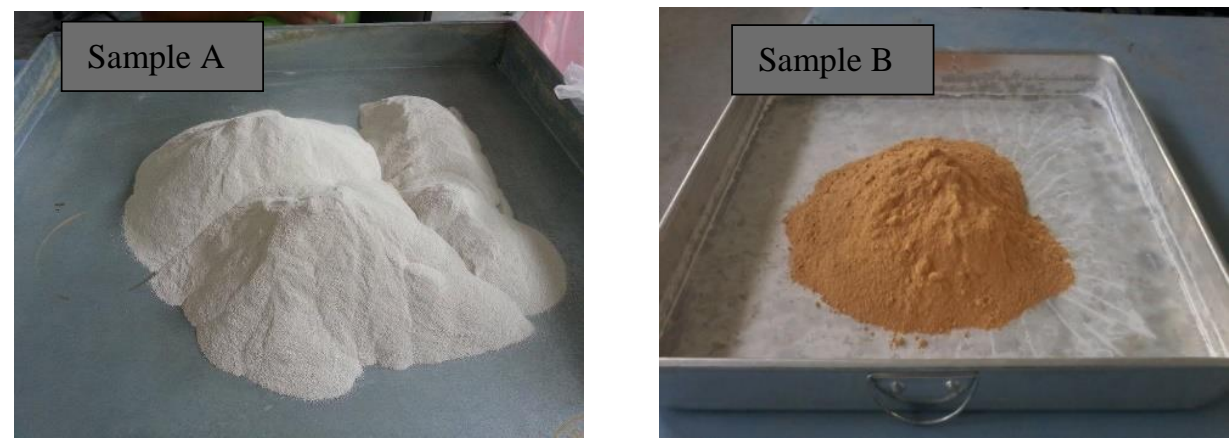

Figure 4 Soil samples 


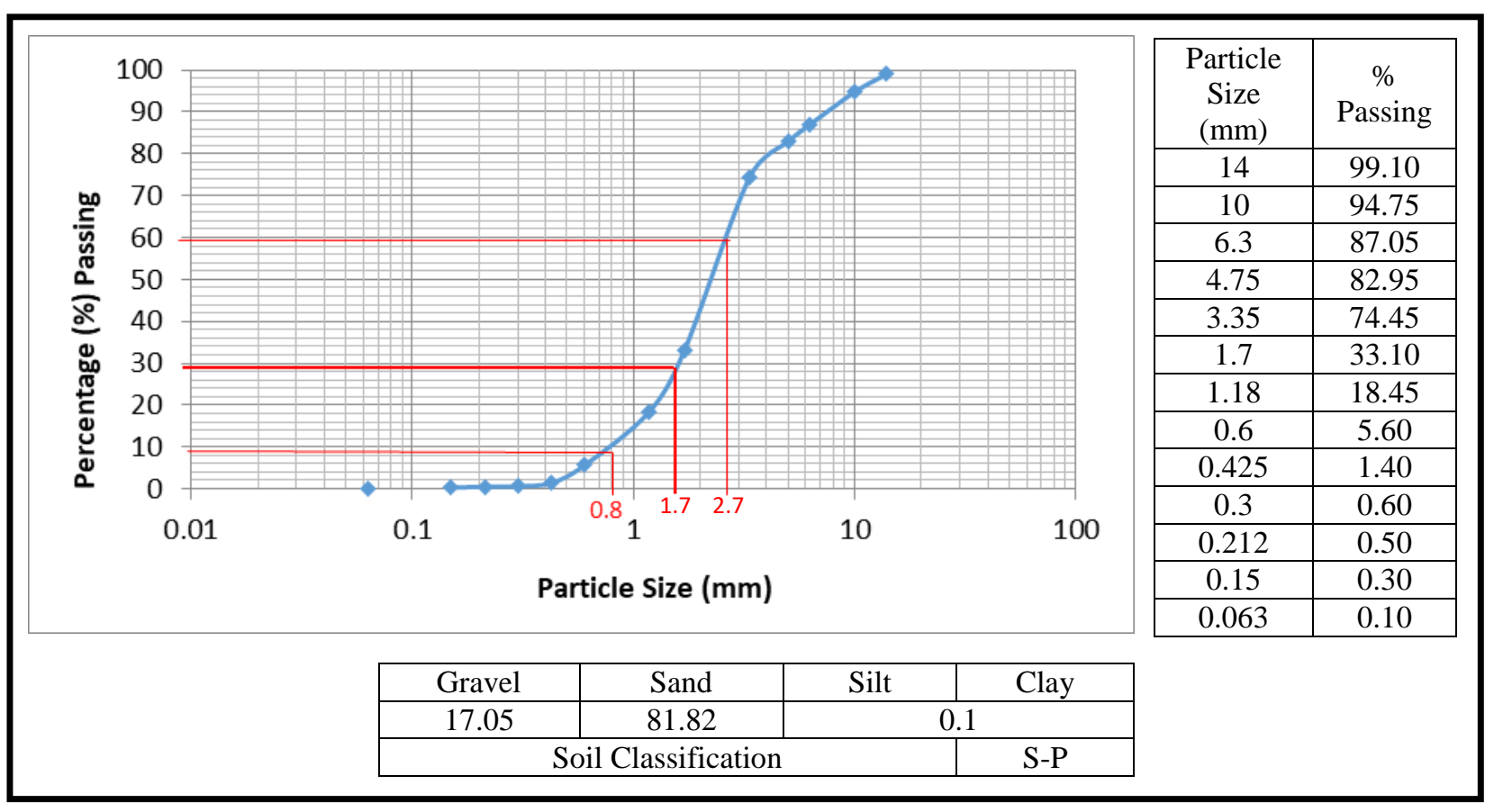

Figure 5 Grain size distribution of soil sample A

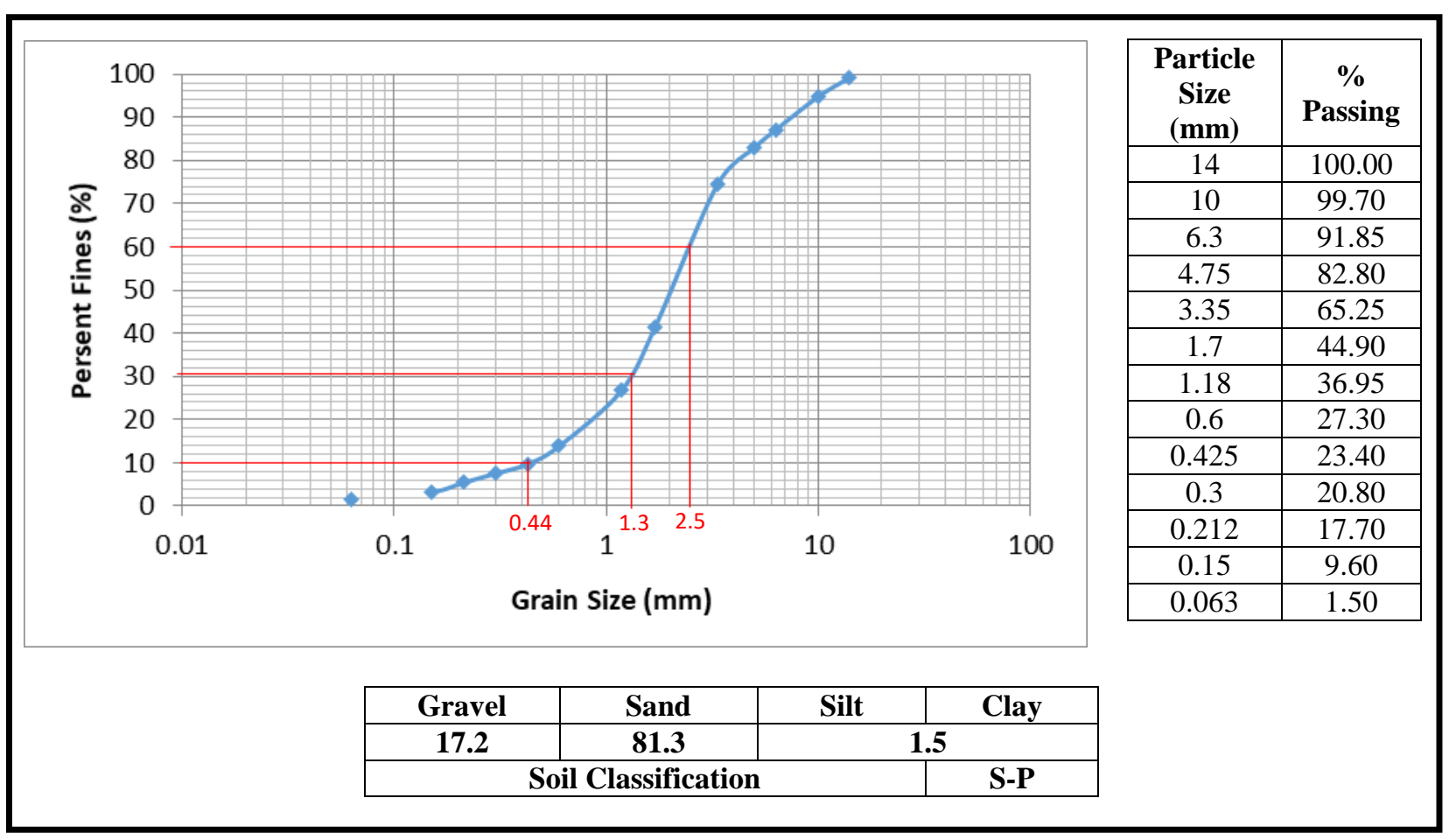

Figure 6 Grain size distribution of soil sample B

\subsection{DEVELOPMENT OF TOPOGRAPHICAL FACTORS}

In this research, topographical factors are a function of sediment yield (SY), surface runoff velocity (RV) and silt and clay compositions (SC). A rainfall simulator was fabricated to simulate equatorial "High-to-Extremely High" rainfall intensity of approximately $150 \mathrm{~mm} / \mathrm{hr}$ on triangular prism, cone and pyramid soil samples. Observations of sediment yield, surface runoff patterns coupled with surface runoff velocity and silt and clay compositions were carried out. Sediment yield can be defined as the amount of soil collected at the outflow end of an observation plot. The experimental soil samples were 
placed under simulated rainfall for 30 minutes with rainfall intensity of about $150 \mathrm{~mm} / \mathrm{hr}$. The mass of soil samples would vary due to the huge amount of soil particles detached by raindrops and transported by surface runoff. The difference of soil sample mass (before and after rainfall simulation) is considered as sediment yield (SY).

Soil loss and sediment yield are strongly related to surface runoff velocity, whereby shorter slope length and steeper slope would result in higher surface runoff velocity that could transport more soil particles downslope. The surface runoff velocity on slope would increase with flow distance. Therefore the peak runoff velocity always occurs downslope; locations $\mathrm{a}, \mathrm{b}, \mathrm{c}, \mathrm{d}$ and e on slopes were selected to compute the surface runoff velocity (RV). Surface runoff from each soil sample was collected in a sediment basin for the 30-minute rainfall simulation. The surface runoff velocity (RV) on slope at locations "a" to "e" can be determined by correlating the flow rate equation $(Q=A V)$ and kinematic equation $\left(V^{2}=2 g h\right)$ as following equations:

Error! Reference source not found.

\section{Error! Reference source not found.}

where

$\mathrm{RV}=$ Surface runoff velocity, $\mathrm{m} / \mathrm{s}$

$\mathrm{Q}=$ Total volume of surface runoff, $\mathrm{m}^{3} / \mathrm{s}$

$\mathrm{A}=$ Cross-sectional area of soil sample where surface runoff flows through $\left(A=L_{n} \mathrm{x} h\right), \mathrm{m}^{2}$

$\mathrm{g}=$ Gravitational constant, $9.81 \mathrm{~m}^{2} / \mathrm{s}$

$\mathrm{h}=$ Height of surface runoff on slope, $\mathrm{m}$

To determine the height of surface runoff on slope (h), equations (6) and (7) can be integrated and become equation (8). The length of cross-sectional area $\left(L_{n}\right)$ of each topographical shape is shown in Table 7.

Error! Reference source not found. $\quad(n=1,2,3,4,5)$

Table 7 Surface runoff pattern of triangular-, cone- and pyramid-shaped

Shape Top View


Surface runoff velocity would carry small soil particles such as silt and clay from higher ground to downslope. However, the soil particles are transported from upslope to downslope whilst the compositions of surface soil would be continually changing; the smallest soil particles would be detached, followed by smaller particles that would be washed downslope. In this study, a small amount of soil samples at locations S1 to S5 (Figure 7) on slope were taken after 15- and 30-minute simulated rainfall events. The soil samples were placed into small containers and oven-dried for 24 hours, subsequently sieved passing through $63 \mu \mathrm{m}$-opening sieve (silt \& clay sizes $<63 \mu \mathrm{m}$ ). Thus, the percentage of silt and clay compositions (SC) can be determined.

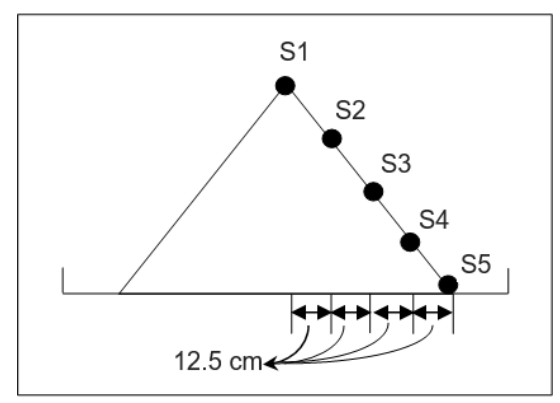

Figure 7 Locations S1 to S5 on soil sample slope

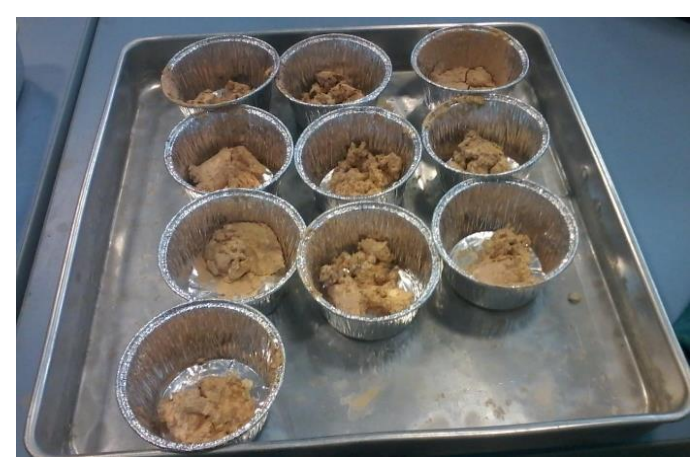

Figure 8 Soil samples collected at locations S1 to S5

In this study, topographical factors $\left(\mathrm{T}_{\mathrm{T}}, \mathrm{T}_{\mathrm{C}} \& \mathrm{~T}_{\mathrm{P}}\right)$ were developed by correlating sediment yield (SY), surface runoff velocity (RV), and silt and clay compositions (SC). These sub-factors have their individual weightages, and those weightages were determined by comparing the percentage differences (\%) of cone versus triangular prism and pyramid versus triangular prism. The topographical factor (T) can be expressed as in Equation 9. Table 7 shows the LS-factor in equatorial regions and its correlation to sediment yield, surface runoff velocity and soil compositions.

\section{$T=[a(S Y)+b(R V)+c(S C)] \times L S_{\text {Error}}$ ? Reference source not found.}

where,

$\mathrm{a}, \mathrm{b}, \mathrm{c}=$ weightage, unitless 
Table 7 LS-factor correlated with sediment yield (SY), surface runoff velocity (RV) and silt and clay compositions (SC)

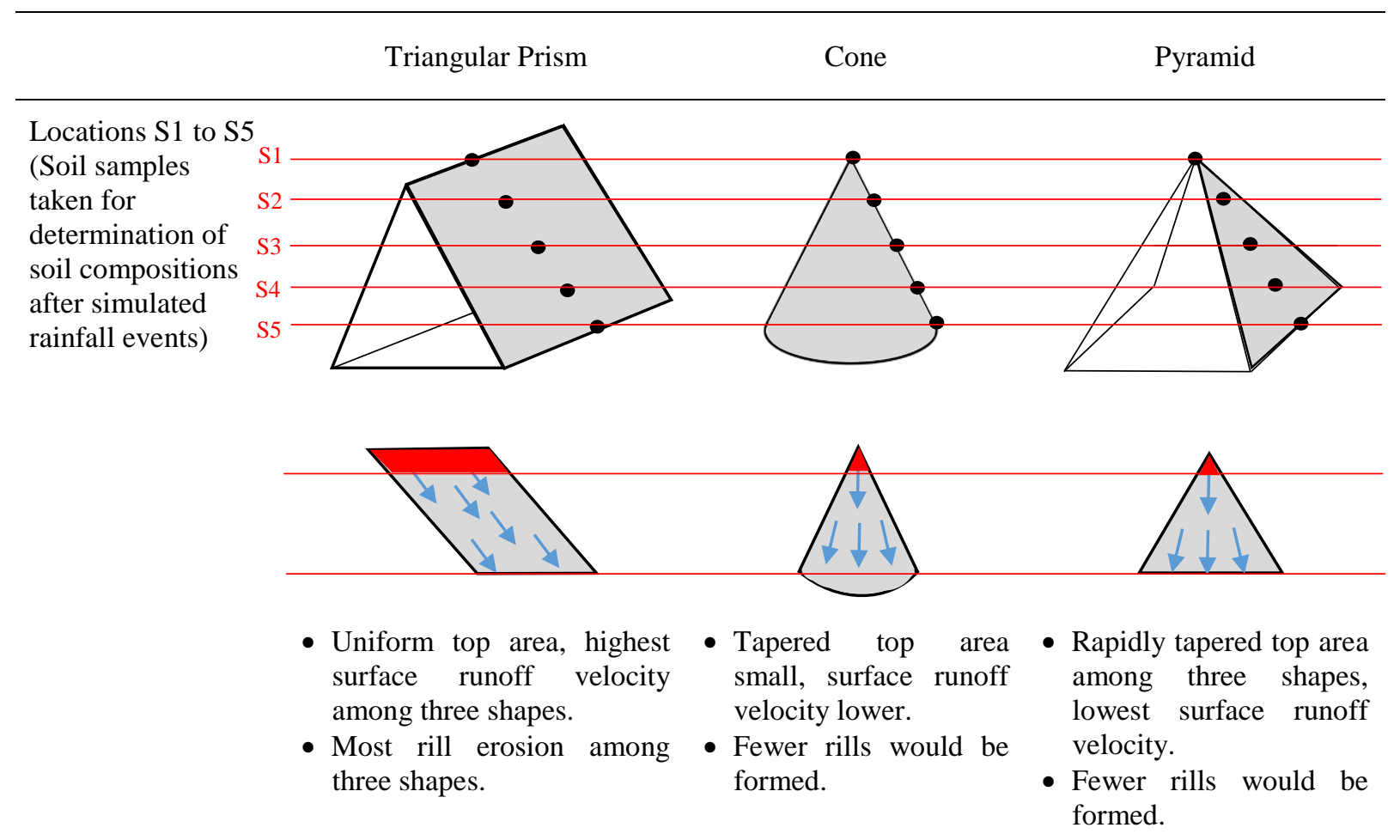

Surface Runoff

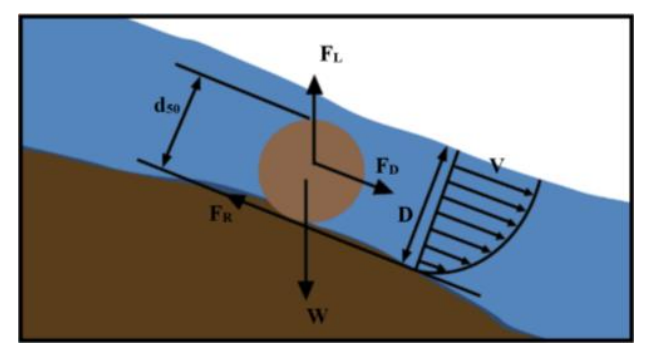

- Forces acting on soil particles when surface runoff occurs including lifting force $\left(\mathrm{F}_{\mathrm{L}}\right)$, drag force due to the velocity of runoff $\left(F_{D}\right)$, resistance force $\left(F_{R}\right)$, and weight due to the gravity force $(\mathrm{W})$. When a critical velocity $(\mathrm{V})$ is exceeded due to the increasing depth of surface runoff (D), the soil particle (depending on particle size) would resuspend to a new position [26].

$$
\mathrm{T}_{\mathrm{T}}=1.0(\mathrm{LS})^{*} \quad \mathrm{~T}_{\mathrm{C}}=<1.0(\mathrm{LS})^{*} \quad \mathrm{~T}_{\mathrm{P}}=<1.0(\mathrm{LS})^{*}
$$

Topographical factor (LS)

$$
\begin{gathered}
(\mathrm{LS})^{*} \text { as the function of sediment yield, surface runoff velocity and silt \& clay } \\
\text { compositions } \\
=\mathrm{a}(\mathrm{SY})+\mathrm{b}(\mathrm{RV})+\mathrm{c}(\mathrm{SC}), \begin{array}{c}
\text { where } \mathrm{a}, \mathrm{b} \& \mathrm{c} \text { represent the weightage of soil loss } \\
\text { contribution }
\end{array}
\end{gathered}
$$

\subsection{SLOPE LENGTH EXPONENT, m VALUE}

Slope length exponent, $\mathrm{m}$, represents the ratio of rill to inter-rill erosion which is used for determination of slope length (L) in the RUSLE $[2,15]$. However, $m$ in the RUSLE considers slope only up to $60 \%$, while missing values of higher slope gradient $(>60 \%)$ probably due to a lack of soil loss data. In this research, $\mathrm{m}$ values were extended to slope gradient $100 \%$ in this research by extrapolation as shown in Table 8. RUSLE's LS values for construction and other highly disturbed soil conditions are adopted in this research as shown in Table 9. 
Table 8: Slope-length exponents (m) for range of slopes and rill/inter-rill erosion classes up to slope gradient $100 \%$

\begin{tabular}{cccc}
\hline $\begin{array}{c}\text { Slope } \\
(\%)\end{array}$ & Low & $\begin{array}{c}\text { Rill/Interrill Ratio }(\mathrm{m}) \\
\text { Moderate }\end{array}$ & High \\
\hline 0.2 & 0.02 & 0.04 & 0.07 \\
0.5 & 0.04 & 0.08 & 0.16 \\
1.0 & 0.08 & 0.15 & 0.26 \\
2.0 & 0.14 & 0.24 & 0.47 \\
3.0 & 0.18 & 0.31 & 0.53 \\
4.0 & 0.22 & 0.36 & 0.57 \\
5.0 & 0.25 & 0.40 & 0.60 \\
6.0 & 0.28 & 0.43 & 0.65 \\
8.0 & 0.32 & 0.48 & 0.68 \\
10.0 & 0.35 & 0.52 & 0.71 \\
12.0 & 0.37 & 0.55 & 0.72 \\
14.0 & 0.40 & 0.57 & 0.74 \\
16.0 & 0.41 & 0.59 & 0.76 \\
20.0 & 0.44 & 0.61 & 0.78 \\
25.0 & 0.47 & 0.64 & 0.79 \\
30.0 & 0.49 & 0.66 & 0.81 \\
40.0 & 0.52 & 0.68 & 0.82 \\
50.0 & 0.54 & 0.70 & 0.83 \\
60.0 & 0.55 & 0.71 & $0.84^{*}$ \\
70.0 & $0.56^{*}$ & $0.72^{*}$ & $0.85^{*}$ \\
80.0 & $0.57^{*}$ & $0.73^{*}$ & $0.86^{*}$ \\
90.0 & $0.58^{*}$ & $0.74 *$ & $0.87^{*}$ \\
\hline 100.0 & $0.59^{*}$ & $0.75^{*}$ & \\
\hline
\end{tabular}

(Sources: McCool et al., 1989; Renard et al., 1997)

Note: $*$ is the $\mathrm{m}$ value by extrapolation.

Table 9 RUSLE LS values for construction and other highly disturbed soil conditions

\begin{tabular}{|c|c|c|c|c|c|c|c|c|c|c|c|c|c|c|c|c|c|}
\hline \multirow{2}{*}{$\begin{array}{c}\text { Slope } \\
\text { gradient } \\
(\%)\end{array}$} & \multicolumn{17}{|c|}{ Horizontal Slope Length (ft) } \\
\hline & $<3$ & 6 & 9 & 12 & 15 & 25 & 50 & 75 & 100 & 150 & 200 & 250 & 300 & 400 & 600 & 800 & 1000 \\
\hline 0.2 & 0.05 & 0.05 & 0.05 & 0.05 & 0.05 & 0.05 & 0.05 & 0.05 & 0.05 & 0.05 & 0.06 & 0.06 & 0.06 & 0.06 & 0.06 & 0.06 & 0.06 \\
\hline 0.5 & 0.07 & 0.07 & 0.07 & 0.07 & 0.07 & 0.07 & 0.08 & 0.08 & 0.09 & 0.09 & 0.10 & 0.10 & 0.10 & 0.11 & 0.12 & 0.12 & 0.13 \\
\hline 1 & 0.09 & 0.09 & 0.09 & 0.09 & 0.09 & 0.10 & 0.13 & 0.14 & 0.15 & 0.17 & 0.18 & 0.19 & 0.20 & 0.22 & 0.24 & 0.26 & 0.27 \\
\hline 2 & 0.13 & 0.13 & 0.13 & 0.13 & 0.13 & 0.16 & 0.21 & 0.25 & 0.28 & 0.33 & 0.37 & 0.40 & 0.43 & 0.48 & 0.56 & 0.63 & 0.69 \\
\hline 3 & 0.17 & 0.17 & 0.17 & 0.17 & 0.17 & 0.21 & 0.30 & 0.36 & 0.41 & 0.50 & 0.57 & 0.64 & 0.69 & 0.80 & 0.96 & 1.10 & 1.23 \\
\hline 4 & 0.20 & 0.20 & 0.20 & 0.20 & 0.20 & 0.26 & 0.38 & 0.47 & 0.55 & 0.68 & 0.79 & 0.89 & 0.98 & 1.14 & 1.42 & 1.65 & 1.86 \\
\hline 5 & 0.23 & 0.23 & 0.23 & 0.23 & 0.23 & 0.31 & 0.46 & 0.58 & 0.68 & 0.86 & 1.02 & 1.16 & 1.28 & 1.51 & 1.91 & 2.25 & 2.55 \\
\hline 6 & 0.26 & 0.26 & 0.26 & 0.26 & 0.26 & 0.36 & 0.54 & 0.69 & 0.82 & 1.05 & 1.25 & 1.43 & 1.60 & 1.90 & 2.43 & 2.89 & 3.30 \\
\hline 8 & 0.32 & 0.32 & 0.32 & 0.32 & 0.32 & 0.45 & 0.70 & 0.91 & 1.10 & 1.43 & 1.72 & 1.99 & 2.24 & 2.70 & 3.52 & 4.24 & 4.91 \\
\hline 10 & 0.35 & 0.37 & 0.38 & 0.39 & 0.40 & 0.57 & 0.91 & 1.20 & 1.46 & 1.92 & 2.34 & 2.72 & 3.09 & 3.75 & 4.95 & 6.03 & 7.02 \\
\hline 12 & 0.36 & 0.41 & 0.45 & 0.47 & 0.49 & 0.71 & 1.15 & 1.54 & 1.88 & 2.51 & 3.07 & 3.60 & 4.09 & 5.01 & 6.67 & 8.17 & 9.57 \\
\hline 14 & 0.38 & 0.45 & 0.51 & 0.55 & 0.58 & 0.85 & 1.40 & 1.87 & 2.31 & 3.09 & 3.81 & 4.48 & 5.11 & 6.30 & 8.45 & 10.40 & 12.23 \\
\hline 16 & 0.39 & 0.49 & 0.56 & 0.62 & 0.67 & 0.98 & 1.64 & 2.21 & 2.73 & 3.68 & 4.56 & 5.37 & 6.15 & 7.60 & 10.26 & 12.69 & 14.96 \\
\hline 20 & 0.41 & 0.56 & 0.67 & 0.76 & 0.84 & 1.24 & 2.10 & 2.86 & 3.57 & 4.85 & 6.04 & 7.16 & 8.23 & 10.24 & 13.94 & 17.35 & 20.57 \\
\hline 25 & 0.45 & 0.64 & 0.80 & 0.93 & 1.04 & 1.56 & 2.67 & 3.67 & 4.59 & 6.30 & 7.88 & 9.38 & 10.81 & 13.53 & 18.57 & 23.24 & 27.66 \\
\hline 30 & 0.48 & 0.72 & 0.91 & 1.08 & 1.24 & 1.86 & 3.22 & 4.44 & 5.58 & 7.70 & 9.67 & 11.55 & 13.35 & 16.77 & 23.14 & 29.07 & 34.71 \\
\hline 40 & 0.53 & 0.85 & 1.13 & 1.37 & 1.59 & 2.41 & 4.24 & 5.89 & 7.44 & 10.35 & 13.07 & 15.67 & 18.17 & 22.95 & 31.89 & 40.29 & 48.29 \\
\hline 50 & 0.58 & 0.97 & 1.31 & 1.62 & 1.91 & 2.91 & 5.16 & 7.20 & 9.13 & 12.75 & 16.16 & 19.42 & 22.57 & 28.60 & 39.95 & 50.63 & 60.84 \\
\hline 60 & 0.63 & 1.07 & 1.47 & 1.84 & 2.19 & 3.36 & 5.97 & 8.37 & 10.63 & 14.89 & 18.92 & 22.78 & 26.51 & 33.67 & 47.18 & 59.93 & 72.15 \\
\hline
\end{tabular}

\subsection{RESULT AND DISCUSSION}

\subsection{SEDIMENT YIELD}

Soil erosion can be defined as the movement of soil particle regardless of distance. The experimental topographical factors $\left(\mathrm{T}_{\mathrm{T}}, \mathrm{T}_{\mathrm{C}} \& \mathrm{~T}_{\mathrm{P}}\right)$ are functions of sediment yield (SY), surface runoff velocity (RV) and percentage of silt and clay content (SC). Measurements of sediment yield, amount of rainwater for 30-minute rainfall simulation on soil sample, and the characteristics or compositions of silt and clay on slope after a rainfall event were carried out. Table 10 shows the recorded values of sediment yield after each simulated rainfall event. 
Table 10 Experimental sediment yield of triangular-prism, cone and pyramid shapes

\begin{tabular}{lcccccc}
\hline \multicolumn{1}{c}{ Shape } & \multicolumn{2}{c}{ Triangular Prism } & \multicolumn{2}{c}{ Cone } & \multicolumn{2}{c}{ Pyramid } \\
\hline \multicolumn{1}{c}{ Soil Sample } & Sample A & Sample B & Sample A & Sample B & Sample A & Sample B \\
Weight Before $(\mathrm{kg})$ & 352.6 & 363.8 & 159.4 & 163.5 & 227.2 & 236.8 \\
Weight After $(\mathrm{kg})$ & 345.5 & 356.2 & 155.8 & 159.7 & 223.0 & 232.2 \\
Sediment Yield $\left(\mathrm{kg} / \mathrm{m}^{2}\right)$ & 7.1 & 7.6 & 3.6 & 3.8 & 4.2 & 4.6 \\
$\begin{array}{l}\text { Average Sediment Yield } \\
\left(\mathrm{kg} / \mathrm{m}^{2}\right)\end{array}$ & & 7.4 & & 3.7 & & 4.4 \\
\hline
\end{tabular}

In Table 10, it is found that the triangular prism soil samples have the highest sediment yield with 7.1 $\mathrm{kg} / \mathrm{m}^{2}$ for sample A and $7.6 \mathrm{~kg} / \mathrm{m}^{2}$ for sample B with an average of $7.4 \mathrm{~kg} / \mathrm{m}^{2}$. The cone soil samples recorded the lowest sediment yield; $3.6 \mathrm{~kg} / \mathrm{m}^{2}$ for sample A and $3.8 \mathrm{~kg} / \mathrm{m}^{2}$ for sample B with an average sediment yield of about $3.7 \mathrm{~kg} / \mathrm{m}^{2}$. It is shown that the cone soil samples yielded approximately $50 \%$ lower than triangular prism. The pyramid sample A and sample B recorded sediment yield values of 4.2 and $4.6 \mathrm{~kg} / \mathrm{m}^{2}$, respectively, and an average sediment yield of about $4.4 \mathrm{~kg} / \mathrm{m}^{2}$ which is $40.5 \%$ lower than the triangular prism soil samples.

\subsection{SURFACE RUNOFF VELOCITY}

Sediment yield is strongly related to surface runoff velocity, whereby higher surface runoff velocity could transport more soil particles downslope, and hence more soil particles can be collected at the end of the experimental plot. The surface runoff patterns for triangular prism, cone and pyramid are illustrated in Table 11. Table 12 and Figure 7 show the summary of calculated velocities at locations "a" to "e" on the three soil sample shapes.

table 12: Surface runoff velocities at locations a-e on soil sample shapes

\begin{tabular}{cccc}
\hline \multirow{2}{*}{ Location } & \multicolumn{3}{c}{ Surface Runoff Velocity, RV $(\mathrm{cm} / \mathrm{s})$} \\
& Triangular Prism & Cone & Pyramid \\
\hline a & 4.17 & 3.59 & 3.37 \\
$\mathrm{~b}$ & 5.26 & 4.52 & 4.25 \\
$\mathrm{c}$ & 6.02 & 5.17 & 4.87 \\
$\mathrm{~d}$ & 6.62 & 5.69 & 5.35 \\
$\mathrm{e}$ & 7.13 & 6.14 & 5.78 \\
\hline
\end{tabular}




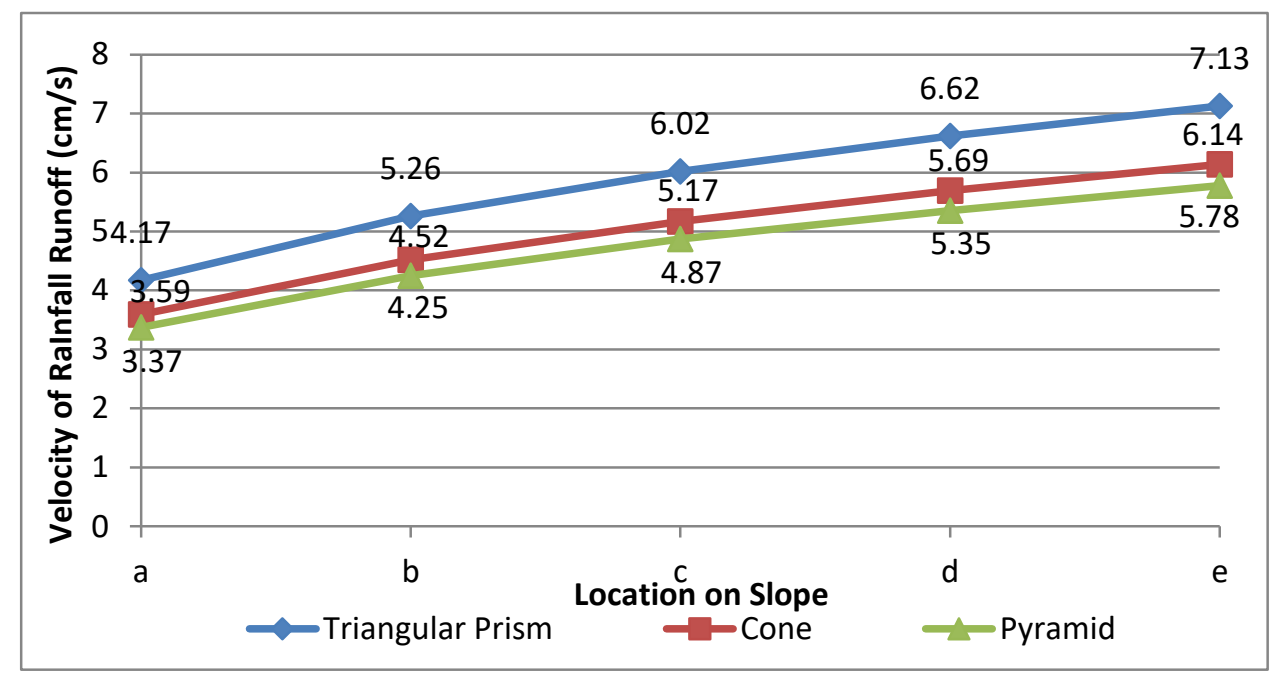

Figure 7 Surface runoff velocities at locations a-e for triangular prism, cone and pyramid soil sample shapes

In Table 12, the triangular prism soil sample shows the highest surface runoff velocity (RV) among the three shapes at 4.17, 5.26, 6.02, 6.62 and $7.13 \mathrm{~cm} / \mathrm{s}$ at locations a, b, c, $\mathrm{d}$ and e, respectively. The cone RV values measured 3.59, 4.52, 5.17, 5.69 and $6.14 \mathrm{~cm} / \mathrm{s}$ at locations "a" to "e", respectively. The pyramid RV values recorded 3.37, 4.25, 4.87, 5.35 and $5.78 \mathrm{~cm} / \mathrm{s}$ at location "a" to "e", respectively, indicating the lowest values recorded among the three shapes. The triangular prism-shaped slope could be used as the reference or as an indicator since the characteristics of slope surface is similar to that of the plane slope surface of the RUSLE. Table 13 compares the dissimilarity in surface runoff velocity (RV) at locations "a" to "e" among the three shapes. The average cone RV value of $14.01 \%$ lower and pyramid RV value of $19.12 \%$ lower were recorded as compared to the observed values of the triangular prism samples.

Table 13 Percentage comparison of surface runoff velocity (RV) at locations "a" to "e"

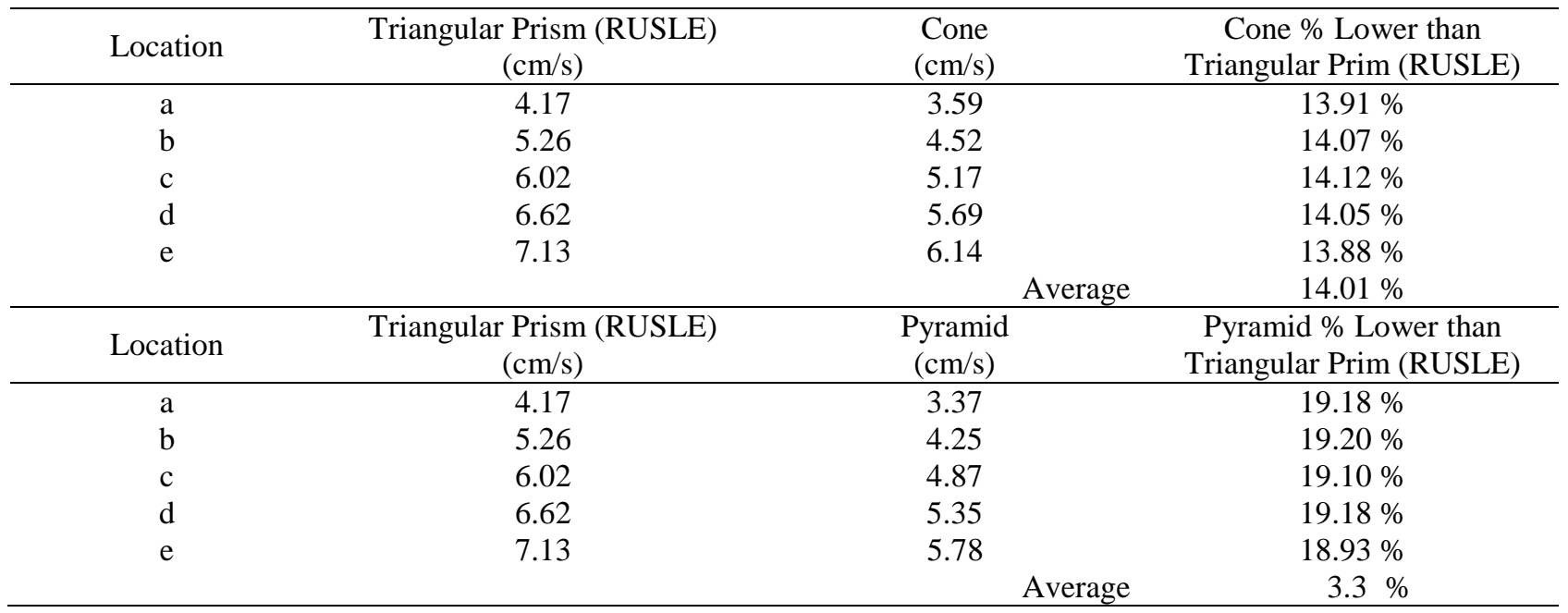

\subsection{SILT AND CLAY COMPOSITIONS}

Small particles such as silt and clay have been transported downslope by surface runoff. The composition of surface soil would be continually changing during rainfall since the smaller particles (silt and clay) were displaced continuously. Small amount of soil samples were taken to test the percentage of silt and clay at locations S1 to S5 after 15-minute and 30-minute rainfall simulation. The results of silt and clay percentages for sample A and sample B are shown in Table 14 and Table 15. 
Table 14 Comparison of silt \& clay of cone-shaped vs triangular prism-shaped

\begin{tabular}{|c|c|c|c|c|c|c|}
\hline \multirow{3}{*}{ _Location } & \multicolumn{6}{|c|}{ Percentage of Silt and Clay at 15-min Rainfall Simulation } \\
\hline & \multicolumn{2}{|c|}{ Triangular Prism } & \multicolumn{2}{|c|}{ Cone } & \multicolumn{2}{|c|}{$\%$ higher or lower } \\
\hline & Sample A & Sample B & Sample A & Sample B & Sample A & Sample B \\
\hline S1 & $11.4 \%$ & $40.7 \%$ & $17.8 \%$ & $52.7 \%$ & $6.4 \%$ & $12.0 \%$ \\
\hline S2 & $12.4 \%$ & $54.8 \%$ & $15.8 \%$ & $47.8 \%$ & $3.4 \%$ & $7.0 \%$ \\
\hline S3 & $13.0 \%$ & $53.3 \%$ & $19.1 \%$ & $48.9 \%$ & $6.1 \%$ & $4.4 \%$ \\
\hline S4 & $14.6 \%$ & $49.2 \%$ & $16.6 \%$ & $50.2 \%$ & $2.0 \%$ & $1.0 \%$ \\
\hline \multirow[t]{4}{*}{ S5 } & $15.1 \%$ & $46.5 \%$ & $15.4 \%$ & $59.6 \%$ & $0.3 \%$ & $13.1 \%$ \\
\hline & & & & Average & $3.6 \%$ & $7.5 \%$ \\
\hline & & & & & \multicolumn{2}{|c|}{$5.6 \%$} \\
\hline & \multicolumn{6}{|c|}{ Percentage of Silt and Clay at 30-min Rainfall Simulation } \\
\hline \multirow[t]{2}{*}{ Location } & \multicolumn{2}{|c|}{ Triangular Prism } & \multicolumn{2}{|c|}{ Cone } & \multicolumn{2}{|c|}{$\%$ higher or lower } \\
\hline & Sample A & Sample B & Sample A & Sample B & Sample A & Sample B \\
\hline S1 & $10.2 \%$ & $27.9 \%$ & $14.6 \%$ & $29.9 \%$ & $4.4 \%$ & $2.0 \%$ \\
\hline S2 & $10.8 \%$ & $54.0 \%$ & $12.7 \%$ & $41.3 \%$ & $1.9 \%$ & $12.7 \%$ \\
\hline S3 & $12.6 \%$ & $42.8 \%$ & $16.0 \%$ & $50.5 \%$ & $3.4 \%$ & $7.7 \%$ \\
\hline S4 & $14.3 \%$ & $49.4 \%$ & $16.4 \%$ & $53.6 \%$ & $2.1 \%$ & $4.2 \%$ \\
\hline \multirow[t]{3}{*}{ S5 } & $13.7 \%$ & $44.2 \%$ & $13.8 \%$ & $48.6 \%$ & $0.1 \%$ & $4.4 \%$ \\
\hline & & & & Average & $2.4 \%$ & $6.2 \%$ \\
\hline & & & & & \multicolumn{2}{|c|}{$4.3 \%$} \\
\hline
\end{tabular}

Table 15 Comparison of silt \& clay of pyramid-shaped $v$ s triangular prism-shaped

\begin{tabular}{|c|c|c|c|c|c|c|}
\hline \multirow{3}{*}{ Location } & \multicolumn{6}{|c|}{ Percentage of Silt and Clay at 15-min Rainfall Simulation } \\
\hline & \multicolumn{2}{|c|}{ Triangular Prism } & \multicolumn{2}{|c|}{ Pyramid } & \multicolumn{2}{|c|}{$\%$ higher or lower } \\
\hline & Sample A & Sample B & Sample A & Sample B & Sample A & Sample B \\
\hline S1 & 11.4 & 40.7 & 11.9 & 30.7 & $4.4 \%$ & $10.0 \%$ \\
\hline $\mathrm{S} 2$ & 12.4 & 54.8 & 9.8 & 30.9 & $21.0 \%$ & $23.9 \%$ \\
\hline S3 & 13.0 & 53.3 & 14.5 & 48.2 & $11.5 \%$ & $5.1 \%$ \\
\hline S4 & 14.6 & 49.2 & 10.7 & 44.0 & $26.7 \%$ & $5.2 \%$ \\
\hline \multirow[t]{4}{*}{ S5 } & 15.1 & 46.5 & 7.5 & 37.3 & $50.3 \%$ & $9.2 \%$ \\
\hline & & & & Average & $22.8 \%$ & $10.7 \%$ \\
\hline & & & & & \multicolumn{2}{|c|}{$16.8 \%$} \\
\hline & \multicolumn{6}{|c|}{ Percentage of Silt and Clay at 30-min Rainfall Simulation } \\
\hline \multirow[t]{2}{*}{ Location } & \multicolumn{2}{|c|}{ Triangular Prism } & \multicolumn{2}{|c|}{ Pyramid } & \multicolumn{2}{|c|}{$\%$ higher or lower } \\
\hline & Sample A & Sample B & Sample A & Sample B & Sample A & Sample B \\
\hline S1 & 10.2 & 27.9 & 9.8 & 25.5 & $3.9 \%$ & $2.4 \%$ \\
\hline S2 & 10.8 & 54.0 & 12.6 & 30.8 & $16.7 \%$ & $23.2 \%$ \\
\hline S3 & 12.6 & 42.8 & 12.1 & 29.6 & $4.0 \%$ & $13.2 \%$ \\
\hline S4 & 14.3 & 49.4 & 11.9 & 33.1 & $16.8 \%$ & $16.3 \%$ \\
\hline \multirow[t]{3}{*}{ S5 } & 13.7 & 44.2 & 6.4 & 43.6 & $53.3 \%$ & $0.6 \%$ \\
\hline & & & & Average & $18.9 \%$ & $11.1 \%$ \\
\hline & & & & & \multicolumn{2}{|c|}{$15.0 \%$} \\
\hline
\end{tabular}

Table 14 shows the composition of silt and clay (sample A and sample B) at the slope surface for the cone and triangular prism samples after 15-minute and 30-minute simulated rainfall events. The compositions of silt and clay on the slope of soil samples at locations S1 to S5 show inconsistency for both sample A and sample B. The composition of silt and clay particles for sample A and sample B for 15-minute rainfall event recorded $3.6 \%$ and $7.5 \%$, respectively. For 30-minute rainfall simulation, the silt and clay recorded $2.4 \%$ and $6.2 \%$ for sample A and sample B, respectively. Hence, the average silt and clay compositions on slopes of cone and triangular prism shapes is $5.0 \%$.

In Table 15, an inconsistency in the composition of silt and clay at locations S1 to S5 was noticed. The average silt and clay percentages for sample A and sample B were $22.8 \%$ and $10.7 \%$ respectively for the 15-minute simulated rainfall event. For the 30-minute simulation, the average compositions of silt 
and clay were approximately $18.9 \%$ and $11.1 \%$ for sample A and sample B, respectively. Hence, the average silt and clay composition on the slopes of pyramid and triangular prism shapes is $15.9 \%$.

\subsection{TOPOGRAPHICAL FACTOR AS FUNCTION OF SEDIMENT YIELD, RUNOFF VELOCITY AND SILT/CLAY COMPOSITION}

In this study, the triangular prism slope can be used as the reference or as an indicator since the characteristics are similar to the plane slope surface of the RUSLE. The cone and pyramid shapes are compared by the degree of similarity or dissimilarity to the triangular prism (Table 16). Table 17 shows the normalized topographical factors or weightages for determination of coefficient of LS-factor in Equation 10.

Table 16 Difference and similarity of cone- and pyramid-shaped as compared to triangular prism-shaped

\begin{tabular}{lcc}
\hline Cone-shaped & \% Difference & \% Similarity \\
\hline Sediment Yield (SY) & $50.0 \%$ & $50.0 \%$ \\
Surface Runoff Velocity (RV) & $14.0 \%$ & $86.0 \%$ \\
\% Silt \& Clay (SC) & $5.0 \%$ & $95.0 \%$ \\
\hline & & $\%$ Similarity \\
\hline Pyramid-shaped & $\%$ Difference & $59.5 \%$ \\
Sediment Yield (SY) & $40.5 \%$ & $80.9 \%$ \\
Surface Runoff Velocity (RV) & $19.1 \%$ & $84.1 \%$ \\
\% Silt \& Clay (SC) & $15.9 \%$ & \\
\hline
\end{tabular}

Table 17 Normalization of topographical factors

\begin{tabular}{|c|c|c|}
\hline No. & Cone-shaped & Pyramid-shaped \\
\hline 1. & $\begin{array}{r}(0.2)(0.50) \\
(0.5)(0.86) \\
+\quad(0.3)(0.95) \\
0.815\end{array}$ & $\begin{array}{r}(0.2)(0.60) \\
(0.5)(0.81) \\
+\quad(0.3)(0.84) \\
0.777\end{array}$ \\
\hline 2. & $\begin{array}{c}(0.25)(0.50) \\
(0.5)(0.86) \\
+\quad(0.25)(0.95) \\
0.793 \\
\end{array}$ & $\begin{array}{c}(0.25)(0.60) \\
(0.5)(0.81) \\
+\quad(0.25)(0.84) \\
0.765 \\
\end{array}$ \\
\hline 3. & $\begin{array}{r}(0.2)(0.50) \\
(0.6)(0.86) \\
+\quad(0.2)(0.95) \\
0.806\end{array}$ & $\begin{array}{r}(0.2)(0.60) \\
(0.6)(0.81) \\
+\quad(0.2)(0.84) \\
0.774\end{array}$ \\
\hline Average & 0.80 & 0.77 \\
\hline
\end{tabular}

In Table 16, the sediment yield of cone and pyramid shapes are 50\% and 59.5\% respectively, similar to the triangular prism; SY values are 0.5 and 0.6 respectively. The surface runoff velocities are $86 \%$ and $80.9 \%$, for cone and pyramid respectively, similar to triangular prism; RV values are 0.86 and 0.81 for cone and pyramid respectively. The degree of similarity of silt and clay compositions of cone and pyramid was $95 \%$ and $84.1 \%$ respectively compared to triangular prism. In Table 17, the average coefficient is 0.8 for cone and 0.77 for pyramid. Therefore, topographical factors can be written as:

Error! Reference source not found. (for triangular prism-shaped terrain)

Error! Reference source not found. (for cone-shaped terrain)

Error! Reference source not found. (for pyramid-shaped terrain) 
Table 18, Table 19 and Table 20 show the normalized Equatorial Topographical Factor for the three terrain shapes.

Table 18 Normalized topographical factor for triangular prism-shaped terrain $\left(\mathrm{T}_{\mathrm{T}}\right)$

\begin{tabular}{|c|c|c|c|c|c|c|c|c|c|c|c|c|c|c|c|c|c|}
\hline \multirow{2}{*}{$\begin{array}{c}\text { Slope } \\
\text { gradient } \\
(\%)\end{array}$} & \multicolumn{17}{|c|}{ Horizontal Slope Length (ft) } \\
\hline & $<3$ & 6 & 9 & 12 & 15 & 25 & 50 & 75 & 100 & 150 & 200 & 250 & 300 & 400 & 600 & 800 & 1000 \\
\hline 0.2 & 0.05 & 0.05 & 0.05 & 0.05 & 0.05 & 0.05 & 0.05 & 0.05 & 0.05 & 0.05 & 0.06 & 0.06 & 0.06 & 0.06 & 0.06 & 0.06 & 0.06 \\
\hline 0.5 & 0.07 & 0.07 & 0.07 & 0.07 & 0.07 & 0.07 & 0.08 & 0.08 & 0.09 & 0.09 & 0.10 & 0.10 & 0.10 & 0.11 & 0.12 & 0.12 & 0.13 \\
\hline 1 & 0.09 & 0.09 & 0.09 & 0.09 & 0.09 & 0.10 & 0.13 & 0.14 & 0.15 & 0.17 & 0.18 & 0.19 & 0.20 & 0.22 & 0.24 & 0.26 & 0.27 \\
\hline 2 & 0.13 & 0.13 & 0.13 & 0.13 & 0.13 & 0.16 & 0.21 & 0.25 & 0.28 & 0.33 & 0.37 & 0.40 & 0.43 & 0.48 & 0.56 & 0.63 & 0.69 \\
\hline 3 & 0.17 & 0.17 & 0.17 & 0.17 & 0.17 & 0.21 & 0.30 & 0.36 & 0.41 & 0.50 & 0.57 & 0.64 & 0.69 & 0.80 & 0.96 & 1.10 & 1.23 \\
\hline 4 & 0.20 & 0.20 & 0.20 & 0.20 & 0.20 & 0.26 & 0.38 & 0.47 & 0.55 & 0.68 & 0.79 & 0.89 & 0.98 & 1.14 & 1.42 & 1.65 & 1.86 \\
\hline 5 & 0.23 & 0.23 & 0.23 & 0.23 & 0.23 & 0.31 & 0.46 & 0.58 & 0.68 & 0.86 & 1.02 & 1.16 & 1.28 & 1.51 & 1.91 & 2.25 & 2.55 \\
\hline 6 & 0.26 & 0.26 & 0.26 & 0.26 & 0.26 & 0.36 & 0.54 & 0.69 & 0.82 & 1.05 & 1.25 & 1.43 & 1.60 & 1.90 & 2.43 & 2.89 & 3.30 \\
\hline 8 & 0.32 & 0.32 & 0.32 & 0.32 & 0.32 & 0.45 & 0.70 & 0.91 & 1.10 & 1.43 & 1.72 & 1.99 & 2.24 & 2.70 & 3.52 & 4.24 & 4.91 \\
\hline 10 & 0.35 & 0.37 & 0.38 & 0.39 & 0.40 & 0.57 & 0.91 & 1.20 & 1.46 & 1.92 & 2.34 & 2.72 & 3.09 & 3.75 & 4.95 & 6.03 & 7.02 \\
\hline 12 & 0.36 & 0.41 & 0.45 & 0.47 & 0.49 & 0.71 & 1.15 & 1.54 & 1.88 & 2.51 & 3.07 & 3.60 & 4.09 & 5.01 & 6.67 & 8.17 & 9.57 \\
\hline 14 & 0.38 & 0.45 & 0.51 & 0.55 & 0.58 & 0.85 & 1.40 & 1.87 & 2.31 & 3.09 & 3.81 & 4.48 & 5.11 & 6.30 & 8.45 & 10.40 & 12.23 \\
\hline 16 & 0.39 & 0.49 & 0.56 & 0.62 & 0.67 & 0.98 & 1.64 & 2.21 & 2.73 & 3.68 & 4.56 & 5.37 & 6.15 & 7.60 & 10.26 & 12.69 & 14.96 \\
\hline 20 & 0.41 & 0.56 & 0.67 & 0.76 & 0.84 & 1.24 & 2.10 & 2.86 & 3.57 & 4.85 & 6.04 & 7.16 & 8.23 & 10.24 & 13.94 & 17.35 & 20.57 \\
\hline 25 & 0.45 & 0.64 & 0.80 & 0.93 & 1.04 & 1.56 & 2.67 & 3.67 & 4.59 & 6.30 & 7.88 & 9.38 & 10.81 & 13.53 & 18.57 & 23.24 & 27.66 \\
\hline 30 & 0.48 & 0.72 & 0.91 & 1.08 & 1.24 & 1.86 & 3.22 & 4.44 & 5.58 & 7.70 & 9.67 & 11.55 & 13.35 & 16.77 & 23.14 & 29.07 & 34.71 \\
\hline 40 & 0.53 & 0.85 & 1.13 & 1.37 & 1.59 & 2.41 & 4.24 & 5.89 & 7.44 & 10.35 & 13.07 & 15.67 & 18.17 & 22.95 & 31.89 & 40.29 & 48.29 \\
\hline 50 & 0.58 & 0.97 & 1.31 & 1.62 & 1.91 & 2.91 & 5.16 & 7.20 & 9.13 & 12.75 & 16.16 & 19.42 & 22.57 & 28.60 & 39.95 & 50.63 & 60.84 \\
\hline 60 & 0.63 & 1.07 & 1.47 & 1.84 & 2.19 & 3.36 & 5.97 & 8.37 & 10.63 & 14.89 & 18.92 & 22.78 & 26.51 & 33.67 & 47.18 & 59.93 & 72.15 \\
\hline 70 & 0.63 & 1.12 & 1.58 & 2.01 & 2.43 & 3.73 & 6.68 & 9.39 & 11.95 & 16.80 & 21.40 & 25.81 & 30.08 & 38.30 & 53.84 & 68.56 & 82.69 \\
\hline 80 & 0.67 & 1.20 & 1.69 & 2.16 & 2.62 & 4.04 & 7.28 & 10.28 & 13.12 & 18.52 & 23.65 & 28.59 & 33.38 & 42.63 & 60.17 & 76.84 & 92.89 \\
\hline 90 & 0.69 & 1.26 & 1.78 & 2.28 & 2.77 & 4.29 & 7.79 & 11.04 & 14.14 & 20.04 & 25.67 & 31.10 & 36.38 & 46.59 & 66.03 & 84.57 & 102.46 \\
\hline 100 & 0.71 & 1.30 & 1.85 & 2.38 & 2.89 & 4.50 & 8.23 & 11.71 & 15.03 & 21.39 & 27.48 & 33.37 & 39.10 & 50.22 & 71.46 & 91.79 & 111.45 \\
\hline
\end{tabular}

Table 19 Normalized topographical factor for cone-shaped terrain $\left(\mathrm{T}_{\mathrm{C}}\right)$

\begin{tabular}{|c|c|c|c|c|c|c|c|c|c|c|c|c|c|c|c|c|c|}
\hline \multirow{2}{*}{$\begin{array}{c}\text { Slope } \\
\text { gradient } \\
(\%)\end{array}$} & \multicolumn{17}{|c|}{ Horizontal Slope Length (ft) } \\
\hline & $<3$ & 6 & 9 & 12 & 15 & 25 & 50 & 75 & 100 & 150 & 200 & 250 & 300 & 400 & 600 & 800 & 1000 \\
\hline 0.2 & 0.04 & 0.04 & 0.04 & 0.04 & 0.04 & $\begin{array}{l}0.04 \\
\end{array}$ & 0.04 & 0.04 & 0.04 & 0.04 & 0.05 & 0.05 & 0.05 & 0.05 & 0.05 & 0.05 & 0.05 \\
\hline 0.5 & 0.06 & 0.06 & 0.06 & 0.06 & 0.06 & 0.06 & 0.06 & 0.06 & 0.07 & 0.07 & 0.08 & 0.08 & 0.08 & 0.09 & 0.10 & 0.10 & 0.10 \\
\hline 1 & 0.07 & 0.07 & 0.07 & 0.07 & 0.07 & 0.08 & 0.10 & 0.11 & 0.12 & 0.14 & 0.14 & 0.15 & 0.16 & 0.18 & 0.19 & 0.21 & 0.22 \\
\hline 2 & 0.10 & 0.10 & 0.10 & 0.10 & 0.10 & 0.13 & 0.17 & 0.20 & 0.22 & 0.26 & 0.30 & 0.32 & 0.34 & 0.38 & 0.45 & 0.50 & 0.55 \\
\hline 3 & 0.14 & 0.14 & 0.14 & 0.14 & 0.14 & 0.17 & 0.24 & 0.29 & 0.33 & 0.40 & 0.46 & 0.51 & 0.55 & 0.64 & 0.77 & 0.88 & 0.98 \\
\hline 4 & 0.16 & 0.16 & 0.16 & 0.16 & 0.16 & 0.21 & 0.30 & 0.38 & 0.44 & 0.54 & 0.63 & 0.71 & 0.78 & 0.91 & 1.14 & 1.32 & 1.49 \\
\hline 5 & 0.18 & 0.18 & 0.18 & 0.18 & 0.18 & 0.25 & 0.37 & 0.46 & 0.54 & 0.69 & 0.82 & 0.93 & 1.02 & 1.21 & 1.53 & 1.80 & 2.04 \\
\hline 6 & 0.21 & 0.21 & 0.21 & 0.21 & 0.21 & 0.29 & 0.43 & 0.55 & 0.66 & 0.84 & 1.00 & 1.14 & 1.28 & 1.52 & 1.94 & 2.31 & 2.64 \\
\hline 8 & 0.26 & 0.26 & 0.26 & 0.26 & 0.26 & 0.36 & 0.56 & 0.73 & 0.88 & 1.14 & 1.38 & 1.59 & 1.79 & 2.16 & 2.82 & 3.39 & 3.93 \\
\hline 10 & 0.28 & 0.30 & 0.30 & 0.31 & 0.32 & 0.46 & 0.73 & 0.96 & 1.17 & 1.54 & 1.87 & 2.18 & 2.47 & 3.00 & 3.96 & 4.82 & 5.62 \\
\hline 12 & 0.29 & 0.33 & 0.36 & 0.38 & 0.39 & 0.57 & 0.92 & 1.23 & 1.50 & 2.01 & 2.46 & 2.88 & 3.27 & 4.01 & 5.34 & 6.54 & 7.66 \\
\hline 14 & 0.30 & 0.36 & 0.41 & 0.44 & 0.46 & 0.68 & 1.12 & 1.50 & 1.85 & 2.47 & 3.05 & 3.58 & 4.09 & 5.04 & 6.76 & 8.32 & 9.78 \\
\hline 16 & 0.31 & 0.39 & 0.45 & 0.50 & 0.54 & 0.78 & 1.31 & 1.77 & 2.18 & 2.94 & 3.65 & 4.30 & 4.92 & 6.08 & 8.21 & 10.15 & 11.97 \\
\hline 20 & 0.33 & 0.45 & 0.54 & 0.61 & 0.67 & 0.99 & 1.68 & 2.29 & 2.86 & 3.88 & 4.83 & 5.73 & 6.58 & 8.19 & 11.15 & 13.88 & 16.46 \\
\hline 25 & 0.36 & 0.51 & 0.64 & 0.74 & 0.83 & 1.25 & 2.14 & 2.94 & 3.67 & 5.04 & 6.30 & 7.50 & 8.65 & 10.82 & 14.86 & 18.59 & 22.13 \\
\hline 30 & 0.38 & 0.58 & 0.73 & 0.86 & 0.99 & 1.49 & 2.58 & 3.55 & 4.46 & 6.16 & 7.74 & 9.24 & 10.68 & 13.42 & 18.51 & 23.26 & 27.77 \\
\hline 40 & 0.42 & 0.68 & 0.90 & 1.10 & 1.27 & 1.93 & 3.39 & 4.71 & 5.95 & 8.28 & 10.46 & 12.54 & 14.54 & 18.36 & 25.51 & 32.23 & 38.63 \\
\hline 50 & 0.46 & 0.78 & 1.05 & 1.30 & 1.53 & 2.33 & 4.13 & 5.76 & 7.30 & 10.20 & 12.93 & 15.54 & 18.06 & 22.88 & 31.96 & 40.50 & 48.67 \\
\hline 60 & 0.50 & 0.86 & 1.18 & 1.47 & 1.75 & 2.69 & 4.78 & 6.70 & 8.50 & 11.91 & 15.14 & 18.22 & 21.21 & 26.94 & 37.74 & 47.94 & 57.72 \\
\hline 70 & 0.50 & 0.90 & 1.27 & 1.61 & 1.94 & 2.98 & 5.34 & 7.51 & 9.56 & 13.44 & 17.12 & 20.65 & 24.06 & 30.64 & 43.07 & 54.85 & 66.16 \\
\hline 80 & 0.53 & 0.96 & 1.36 & 1.73 & 2.09 & 3.23 & 5.82 & 8.22 & 10.50 & 14.82 & 18.92 & 22.87 & 26.71 & 34.11 & 48.14 & 61.48 & 74.32 \\
\hline 90 & 0.55 & 1.01 & 1.43 & 1.83 & 2.21 & 3.43 & 6.23 & 8.83 & 11.31 & 16.04 & 20.54 & 24.88 & 29.11 & 37.28 & 52.83 & 67.66 & 81.97 \\
\hline 100 & 0.57 & 1.04 & 1.48 & 1.90 & 2.31 & 3.60 & 6.58 & 9.36 & 12.03 & 17.12 & 21.98 & 26.69 & 31.28 & 40.18 & 57.17 & 73.43 & 89.16 \\
\hline
\end{tabular}

Table 20 Normalized topographical factor for pyramid-shaped terrain $\left(T_{P}\right)$

\begin{tabular}{cccccccccccccccccc}
\hline $\begin{array}{c}\text { Slope } \\
\text { gradient } \\
(\%)\end{array}$ & $<3$ & 6 & 9 & 12 & 15 & 25 & 50 & 75 & 100 & 150 & 200 & 250 & 300 & 400 & 600 & 800 & 1000 \\
\hline 0.2 & 0.04 & 0.04 & 0.04 & 0.04 & 0.04 & 0.04 & 0.04 & 0.04 & 0.04 & 0.04 & 0.05 & 0.05 & 0.05 & 0.05 & 0.05 & 0.05 & 0.05 \\
0.5 & 0.05 & 0.05 & 0.05 & 0.05 & 0.05 & 0.05 & 0.06 & 0.06 & 0.07 & 0.07 & 0.08 & 0.08 & 0.08 & 0.08 & 0.09 & 0.09 & 0.10 \\
1 & 0.07 & 0.07 & 0.07 & 0.07 & 0.07 & 0.08 & 0.10 & 0.11 & 0.12 & 0.13 & 0.14 & 0.15 & 0.15 & 0.17 & 0.18 & 0.20 & 0.21 \\
2 & 0.10 & 0.10 & 0.10 & 0.10 & 0.10 & 0.12 & 0.16 & 0.19 & 0.22 & 0.25 & 0.28 & 0.31 & 0.33 & 0.37 & 0.43 & 0.49 & 0.53 \\
3 & 0.13 & 0.13 & 0.13 & 0.13 & 0.13 & 0.16 & 0.23 & 0.28 & 0.32 & 0.39 & 0.44 & 0.49 & 0.53 & 0.62 & 0.74 & 0.85 & 0.95 \\
\hline
\end{tabular}




\begin{tabular}{|c|c|c|c|c|c|c|c|c|c|c|c|c|c|c|c|c|c|}
\hline 4 & 0.15 & 0.15 & 0.15 & 0.15 & 0.15 & 0.20 & 0.29 & 0.36 & 0.42 & 0.52 & 0.61 & 0.69 & 0.75 & 0.88 & 1.09 & 1.27 & 1.43 \\
\hline 5 & 0.18 & 0.18 & 0.18 & 0.18 & 0.18 & 0.24 & 0.35 & 0.45 & 0.52 & 0.66 & 0.79 & 0.89 & 0.99 & 1.16 & 1.47 & 1.73 & 1.96 \\
\hline 6 & 0.20 & 0.20 & 0.20 & 0.20 & 0.20 & 0.28 & 0.42 & 0.53 & 0.63 & 0.81 & 0.96 & 1.10 & 1.23 & 1.46 & 1.87 & 2.23 & 2.54 \\
\hline 8 & 0.25 & 0.25 & 0.25 & 0.25 & 0.25 & 0.35 & 0.54 & 0.70 & 0.85 & 1.10 & 1.32 & 1.53 & 1.72 & 2.08 & 2.71 & 3.26 & 3.78 \\
\hline 10 & 0.27 & 0.28 & 0.29 & 0.30 & 0.31 & 0.44 & 0.70 & 0.92 & 1.12 & 1.48 & 1.80 & 2.09 & 2.38 & 2.89 & 3.81 & 4.64 & 5.41 \\
\hline 12 & 0.28 & 0.32 & 0.35 & 0.36 & 0.38 & 0.55 & 0.89 & 1.19 & 1.45 & 1.93 & 2.36 & 2.77 & 3.15 & 3.86 & 5.14 & 6.29 & 7.37 \\
\hline 14 & 0.29 & 0.35 & 0.39 & 0.42 & 0.45 & 0.65 & 1.08 & 1.44 & 1.78 & 2.38 & 2.93 & 3.45 & 3.93 & 4.85 & 6.51 & 8.01 & 9.42 \\
\hline 16 & 0.30 & 0.38 & 0.43 & 0.48 & 0.52 & 0.75 & 1.26 & 1.70 & 2.10 & 2.83 & 3.51 & 4.13 & 4.74 & 5.85 & 7.90 & 9.77 & 11.52 \\
\hline 20 & 0.32 & 0.43 & 0.52 & 0.59 & 0.65 & 0.95 & 1.62 & 2.20 & 2.75 & 3.73 & 4.65 & 5.51 & 6.34 & 7.88 & 10.73 & 13.36 & 15.84 \\
\hline 25 & 0.35 & 0.49 & 0.62 & 0.72 & 0.80 & 1.20 & 2.06 & 2.83 & 3.53 & 4.85 & 6.07 & 7.22 & 8.32 & 10.42 & 14.30 & 17.89 & 21.30 \\
\hline 30 & 0.37 & 0.55 & 0.70 & 0.83 & 0.95 & 1.43 & 2.48 & 3.42 & 4.30 & 5.93 & 7.45 & 8.89 & 10.28 & 12.91 & 17.82 & 22.38 & 26.73 \\
\hline 40 & 0.41 & 0.65 & 0.87 & 1.05 & 1.22 & 1.86 & 3.26 & 4.54 & 5.73 & 7.97 & 10.06 & 12.07 & 13.99 & 17.67 & 24.56 & 31.02 & 37.18 \\
\hline 50 & 0.45 & 0.75 & 1.01 & 1.25 & 1.47 & 2.24 & 3.97 & 5.54 & 7.03 & 9.82 & 12.44 & 14.95 & 17.38 & 22.02 & 30.76 & 38.99 & 46.85 \\
\hline 60 & 0.49 & 0.82 & 1.13 & 1.42 & 1.69 & 2.59 & 4.60 & 6.44 & 8.19 & 11.47 & 14.57 & 17.54 & 20.41 & 25.93 & 36.33 & 46.15 & 55.56 \\
\hline 70 & 0.48 & 0.87 & 1.22 & 1.55 & 1.87 & 2.87 & 5.14 & 7.23 & 9.20 & 12.94 & 16.48 & 19.87 & 23.16 & 29.49 & 41.46 & 52.79 & 63.67 \\
\hline 80 & 0.51 & 0.92 & 1.30 & 1.67 & 2.01 & 3.11 & 5.61 & 7.91 & 10.10 & 14.26 & 18.21 & 22.02 & 25.71 & 32.83 & 46.33 & 59.17 & 71.53 \\
\hline 90 & 0.53 & 0.97 & 1.37 & 1.76 & 2.13 & 3.31 & 6.00 & 8.50 & 10.89 & 15.43 & 19.77 & 23.95 & 28.01 & 35.88 & 50.85 & 65.12 & 78.89 \\
\hline 100 & 0.55 & 1.00 & 1.42 & 1.83 & 2.22 & 3.47 & 6.33 & 9.01 & 11.58 & 16.47 & 21.16 & 25.69 & 30.11 & 38.67 & 55.03 & 70.68 & 85.82 \\
\hline
\end{tabular}

\subsection{CONCLUSION}

In conclusion, topographical factors $\left(\mathrm{T}_{\mathrm{T}}, \mathrm{T}_{\mathrm{C}} \& \mathrm{~T}_{\mathrm{P}}\right)$ in equatorial regions were found as functions of sediment yield (SY), surface runoff velocity (RV) and silt and clay compositions (SC). The triangular prism shape was used as an indicator for cone and pyramid shapes due to the similar shape to RUSLE's plot which is an inclined plane surface. Cone showed 50\% similarity of sediment yield, $86 \%$ of surface runoff velocity and $95 \%$ of silt and clay compositions compared to triangular prism. The similarity of sediment yield, surface runoff velocity and silt and clay compositions were $59.5 \%, 80.9 \%$ and $84.1 \%$ respectively compared to triangular prism. Therefore, this research experimentally developed the topographical factors for triangular prism-shaped, cone-shaped and pyramid-shaped landscapes: Error! Reference source not found. (Triangular Prism), Error! Reference source not found. (Cone) andError! Reference source not found. (Pyramid). These Topographical Factors $\left(T_{T}, T_{C} \& T_{P}\right)$ can be used to replace the RUSLE's and MUSLE's LS to estimate the soil loss and sediment yield in equatorial regions.

\section{REFERENCES}

[1] Wischmeier, W.H., \& Smith, D.D. (1958). Rainfall Energy and Its Relationship to Soil Loss. Transaction American Geophysical Union, 39(2): 285-291.

[2] Moore, I.D., \& Wilson, J.P. (1992). Length-slope Factors for the Revised Universal Soil Loss Equation: Simplified Method of Estimation. Journal of Soil and Water Conservation, 47(5): 423-428.

[3] El-Hassanin, A.S., Labib, T.M. and Gaber, E.I. (1993). Effect of Vegetation Cover and Landscape on Runoff and Soil Losses from Watersheds of Burundi. Agricultural Ecosystems and Environment. 43, 301-308.

[4] Renard, K.G., Foster, G.R., Weesies, G.A., McCool, D.K. and Yoder, D.C. (1997). Predicting Soil Erosion by Water: A Guide to Conservation Planning with the Revised Universal Soil Loss Equation. U.S. Department of Agriculture, Agriculture Handbook 703, pp.384.

[5] Jones, D.S., Kowalski, D.G., \& Shaw, R.B. (1996). Calculating Revised Universal Soil Loss Equation (RUSLE) Estimates on Department of Defense Lands: A Review of RUSLE Factors and U.S. Army Land Condition-Trend Analysis (LCTA) Data Gaps.

[6] Liu, B.Y., Nearing, M.A., Shi, P.J., \& Jia, Z.W. (2000). Slope Length Effects on Soil Loss for Steep Slopes. Soil Science Society of America Journal, 64: 1759-1763.

[7] Desmet, P.J.J., and Govers, G. (1996). A GIS-procedure for automatically calculating the USLE LS-factor on topographically complex landscape units. Journal of Soil and Water Conservation, 51(5), 427-433.

[8] Mukherjee, S., Joshi, P.K., Mukherjee, S., Ghosh, A., Garg, R.D. \& Mukhopadhyay, A. (2014). Evaluation of vertical accuracy of open source Digital Elevation Model (DEM). International Journal of Applied Earth Observation and Geoinformation, 21:205-217.

[9] Panagos, P., Borrelli, P. and Meusburger, K. (2015). A New European Slope Length and Steepness Factor (LSFactor) for Modeling Soil Erosion by water. Geosciences 5, 117-126. 
[10] Lal, R. (1994). Global Soil Erosion by Water and Carbon Dynamics. In Lal, R., Kimble, J.M., Levine, E. \& Stewart, B.A. (Eds). Soils and Global Change. CRC/Lewis Boca Raton, FL: 131-41.

[11] Zingg, A.W. (1940). Degree and Length of Land Slope as It Affects Soil Loss in Runoff. Agricultural Engineering, 21(2):59-64.

[12] Musgrave, G.W. (1947). The Quantitative Evaluation of Factors in Water Erosion - A First Approximation. Journal of Soil and Water Conservation, 2: 133-138.

[13] Moore, I. and Burch, G. (1986) Physical basis of the length-slope factor in the Universal Soil Loss Equation. Soil Society of America Journal, 50: 1294 - 1298.

[14] McCool, D.K., Brown, L.C., Foster, G.R., Mutchler, C.K., and Meyer L.D. (1987). Revised Slope Steepness factor for the Universal Soil Loss Equation. Transaction of the America Society of Agricultural Engineers, 30:1387-1396.

[15] McCool, D.K., Brown, L.C., Foster, G.R., Mutchler, C.K., \& Meyer L.D. (1989). Revised Slope factor for the Universal Soil Loss Equation. Transaction of the America Society of Agricultural Engineers, 32:1571-1576.

[16] Sharma, K., Singh, H., \& Pareek, O. (1983). Rainwater Infiltration into a Bare Loamy Sand. Hydrological Science Journal, 28: 417-424.

[17] Luk, S.H., Cai, Q., \& Wang, G.P. (1993). Effects of Surface Crusting and Slope Gradient on Soil and Water Losses in the Illy Loess Egion, North China. Catena, 24: 29-45.

[18] Fox, D.M., Bryan, R.B., \& Price, A.G. (1997). The Influence of Slope Angle on Final Infiltration Rate for Interrill Conditions. Geoderma, 80: 181-194.

[19] McDonald, R.C., Isbell, J.G., Speight, J.G., Walker, J., \& Hopkins, M.S. (1984). Australian Soil and Land Survey. Field Handbook. Melbourne, Australia: Inkata Press.

[20] Liu, B.Y., \& Tang, K.L. (1987). Slope Gradient Classification and Distribution of the Slope Gradient of Wangdog Watershed. (In Chinese). Bulletin Soil Water Conservation, 7(3): 59-64.

[21] Liu, B.Y., Nearing, M.A., and Risse, L.M. (1994). Slope Gradient Effects on soil loss for steep slopes. Transaction of the America Society of Agricultural Engineers, 37:1835-1840.

[22] Wischmeier, W.H. and Smith, D.D. (1978). Predicting Rainfall Erosion Losses - A Guide to Conservation Planning. U.S. Department of Agriculture, Agriculture Handbook No.537. Washington, DC, USA.

[23] Nearing, M.A. (1997). A Single, Continuous Function for Slope Steepness Influence on Soil Loss. Soil Science Society of America Journal, 61:917-919.

[24] Wischmeier, W.H. (1959). A Rainfall Erosion Index for a Universal Soil-loss Equation. Soil Science Society of America Journal, 23(3): 246-249.

[25] Roux, L.J.S., \& Roos, Z.N. (1991). The Effect of Rainfall Factors and Antecedent Soil Moisture on Soil Loss on a Low-angled Slope in a Semi-arid Climate. Water SA WASADV, 17(3): 167-172.

[26] Tippayawong, N., \& Preechawuttipong, I. (2011). Analysis of Microparticle Resuspension in Turbulent Flows with Horizontally Vibrating Surface. Australian Journal of Basic and Applied Sciences, 5(7): 356-363. 